\title{
The sustainability of Brazilian ethanol_An assessment of the possibilities of certified production
}

\author{
Edward Smeets ${ }^{a, *}$, Martin Junginger ${ }^{a}$, André Faaij ${ }^{a}$, Arnaldo Walter $^{b}$, Paulo Dolzan $^{b}$, \\ Wim Turkenburg ${ }^{a}$ \\ ${ }^{a}$ Department of Science, Technology and Society, Copernicus Institute for Sustainable Development and Innovation, Utrecht University, \\ Heidelberglaan 2, 3584 CS Utrecht, The Netherlands \\ bState University of Campinas-Unicamp, 13083-970 Campinas, São Paulo, Brazil
}

\section{A R T I C L E I N F O}

Article history:

Received 1 February 2007

Received in revised form

14 January 2008

Accepted 16 January 2008

Available online 11 March 2008

Keywords:

Sugarcane

Ethanol

Sustainability

Certification system

São Paulo

Brazil

\begin{abstract}
A B S T R A C T
In this article the environmental and socio-economical impacts of the production of ethanol from sugarcane in the state of São Paulo (Brazil) are evaluated. Subsequently, an attempt is made to determine to what extent these impacts are a bottleneck for a sustainable and certified ethanol production. Seventeen environmental and socioeconomic areas of concern are analysed. Four parameters are used to evaluate if an area of concern is a bottleneck: (1) the importance of the area of concern, based on the severity of the impact and the frequency of which an aspect is mentioned in the literature as an area of concern, (2) the availability of indicators and criteria, (3) the necessity of improvement strategies to reach compliance with Brazilian and/or (inter) national legislation, standards, guidelines and sustainability criteria, and (4) the impact of these improvement strategies on the costs and potential of ethanol production. Fourteen areas of concern are classified as a minor or medium bottleneck. For 7 areas of concern the additional costs to avoid or reduce undesirable effects have been calculated at $\leqslant+10 \%$ for each area of concern. Due to higher yields and overlapping costs the total additional production costs of compliance with various environmental and socio-economic criteria are about $+36 \%$. This study also shows that the energy input to output ratio can be increased and the greenhouse gas emissions reduced by increasing the ethanol production per tonne cane and by increasing the use of sugarcane waste for electricity production. A major bottleneck for a sustainable and certified production is the increase in cane production and the possible impacts on biodiversity and the competition with food production. Genetically modified cane is presently being developed, but is at this moment not (yet) applied. Both a ban on and the allowance of the use of genetically modified cane could become a major bottleneck considering the potentially large benefits and disadvantages, that are both highly uncertain at this moment. The approach demonstrated in this report provides a useful framework for the development of a practically applicable certification system, but further monitoring and research is required to reduce gaps in knowledge in combination with stakeholder consultation (particularly with respect to the three bottlenecks identified in this article).
\end{abstract}

(c) 2008 Elsevier Ltd. All rights reserved.

\footnotetext{
*Corresponding author. Tel.: +3130 2537688; fax: +31302537601.

E-mail address: E.M.W.Smeets@uu.nl (E. Smeets).
}

0961-9534/\$ - see front matter (c 2008 Elsevier Ltd. All rights reserved.

doi:10.1016/j.biombioe.2008.01.005 


\section{Introduction}

The production of biofuels has been growing steadily during the previous years and is projected to increase further during the coming decades. This goes especially for the production of ethanol from sugarcane, of which Brazil is a major producer. The production of ethanol in Brazil increased from $0.6 \mathrm{Mm}^{3}$ in 1975 (the start of the Brazilian ethanol programme) to $12 \mathrm{Mm}^{3}$ in 1995 and $16 \mathrm{Mm}^{3}$ in 2005 , which equals half the global bioethanol production [1,2]. This production is projected to increase to up to $36 \mathrm{Mm}^{3}$ in 2015 [3]. Further, Brazilian ethanol is the most important contributor to the international trade of ethanol, with an estimated share of about $60 \%$ in 2005 [4].

Concerns have been raised about the ecological, economical and social impacts of bioethanol production and to what extent the total sum of these impacts undermines a sustainable development and use of this energy source. Many studies have been carried out to assess the impacts of ethanol production (e.g., [5-11]), most of which focus however on a small number of impacts. Also, several projects have been undertaken and are ongoing to develop a certification system to ensure a sustainable production and use of bioenergy; see Lewandowski and Faaij [12] and the article of Van Dam et al. elsewhere in this special issue for an overview of recent developments. It can be concluded that there are many ongoing efforts to develop certification systems, but only a few systems are operational. In this article, we present a systematic attempt to formulate a set of practically applicable sustainability criteria that are (potential) bottlenecks for a sustainable and certified bioenergy production. We apply these criteria to the production of ethanol from sugarcane in the state of São Paulo (SP) in Brazil. This case was chosen as case study for two reasons. (1) Ethanol is the world's most important biofuel. (2) The combination of fertile soils, favourable climate, relative good infrastructure and the Brazilian ethanol program (ProAlcool) has made SP the world's most important ethanol-producing region with a share of $21 \%$ of the total worldwide production [1,2]. Further, a large fraction of the increase in ethanol production in Brazil during the next decade is expected to be realized in SP $[3,13]$.

The formulation and application of criteria are done in five steps. First, the key areas of concern when discussing sustainability criteria are selected (Section 2); these are also called issues. Second, a literature review is carried out to analyse the ecological and socio-economical impacts of ethanol production in SP. Third, an assessment is made of the level of compliance of the present impact of ethanol production with Brazilian and (inter) national legislation, standards and guidelines and also with sustainability criteria that are included in existing certification systems for agricultural and wood products. Fourth, the implications for certification are discussed, by assessing to what extent practically applicable indicators and criteria are available or need to be developed, by investing what kind of improvement strategies can be applied to meet sustainability criteria and by estimating the impact of these improvements on the ethanol production costs and/or the amount of ethanol that can be produced sustainable. An indicator is a quantity that can be
Table 1 - The 17 areas of concern included in this article and the respective sections in which they are analysed

\section{Area of concern}

1

2

3

4

5

6

7

8

Socio-economical

9

10

11

12

13

15

16

17
Ecological

\section{Section}

3.2

3.2.1

3.2.2

3.2.3

3.2.4

3.2 .5

3.2 .6

3.2.7

3.2 .8

3.3

3.3.1

3.3.3

3.3.4

3.3.2

3.3 .5

3.3.6

3.3.7

3.3 .8

4 used to quantify the impact (e.g., the water collection rate for cane milling, in $\mathrm{m}^{3}$ per tonne ( $\mathrm{t}$ ) cane). A criterion is the value of this unit that can be used to define when the impact is sustainable (e.g., the water collection rate should be below $1.0 \mathrm{~m}^{3} \mathrm{t}^{-1}$ cane). The results of step two, three and four, are presented in Sections 3.2 and 3.3. Fifth, the results are summarized and conclusions are formulated to what extent each area of concern is a bottleneck for certification (Section 5). ${ }^{1}$ Specific attention is hereby paid to gaps in knowledge.

\section{Approach and methodology}

The approach and methodology applied in this research is taken from the FairBiotrade research project [15]. In this project the methodology was applied to a (fictive) woody bioenergy crop production system in Brazil (eucalyptus) and Ukraine (poplar). In this article we apply it to an existing bioenergy production system, namely the production of ethanol from sugarcane in the state of São Paulo (SP) in Brazil. Seventeen key areas of concern are selected and included in our work (Table 1). The selection is based on a review of the literature about the environmental and socio-economic impacts of ethanol production in Brazil and also based on a list of 127 sustainability issues that are relevant for the production and trade of bioenergy as identified by Lewandowski and Faaij [16].

Some areas of concern deal with a number of sustainability issues. For example, the level of wages is identified as an area of concern, which overlaps with the issues 'poverty reduction' and 'access to health care services'. Some issues are excluded from our investigations, because we were not able to operationalize them into criteria and indicators that can be

\footnotetext{
${ }^{1}$ This article is an updated version of the report "Sustainability of Brazilian ethanol" [14].
} 
Table 2 - The four aspects based on which conclusions are drawn to what extent and area of concern is a bottleneck for a sustainable, certified ethanol production in São Paulo, including the valuation in words and in points

\begin{tabular}{llll}
\hline $\begin{array}{l}\text { (1) Importance of the } \\
\text { area of concern }\end{array}$ & $\begin{array}{c}\text { (2) Availability of } \\
\text { indicators and } \\
\text { criteria }\end{array}$ & $\begin{array}{l}\text { (3) Necessity of } \\
\text { improvement } \\
\text { strategies }\end{array}$ & $\begin{array}{l}\text { (4) Impact of improvement strategies on } \\
\text { the costs and potential (quantity) of } \\
\text { ethanol production }\end{array}$ \\
\hline $\begin{array}{l}\text { High importance (3) } \\
\text { Medium importance (2) }\end{array}$ & $\begin{array}{l}\text { Low availability (3) } \\
\text { Medium availability (2) } \\
\text { High availability (1) }\end{array}$ & $\begin{array}{l}\text { High necessity (3) } \\
\text { Medium necessity (2) } \\
\text { Low necessity (1) }\end{array}$ & $\begin{array}{l}\text { High impact (3) } \\
\text { Medium impact (2) } \\
\text { Low impact (1) }\end{array}$ \\
\hline
\end{tabular}

quantified. For instance the issue 'discrimination of women' is, although very relevant, excluded.

Next, we determine to what extent each area of concern is a potential bottleneck for a sustainable, certified ethanol production in SP, based on the five steps described below. The scope of our analysis is limited to the direct impacts, thereby ignoring indirect and induced impacts. ${ }^{2}$ This approach is similar to existing certification systems and we estimate that the formulation of practically usable certifications system becomes much more difficult if indirect and induced impacts are included too. An exception is made for two areas of concern (biodiversity and employment), since indirect and induced impacts seem particularly important for these issues.

1. Impact assessment of ethanol production: A quantitative analysis is made (as far as possible) of the historic, present and future ecological and socio-economical impacts of ethanol production based on a literature review and consultation with Brazilian partners.

2. Legislation and guidelines: An overview is given of Brazilian and (inter) national legislation and guidelines and of criteria published in the literature that are relevant for sustainable ethanol production.

3. Options for sustainable ethanol production: The practical possibilities and limitations for a sustainable and certified ethanol production are analysed, using the results from Steps 1 and 2, namely:

(a) The availability of practically applicable indicators and criteria included in Brazilian and/or (inter) national legislation, guidelines and certification systems.

(b) The availability and effectiveness of practically applicable improvement strategies.

(c) The extent to which improvement strategies are required to meet the legislation, guidelines and sustainability criteria referred to under (a).

(d) The extent to which improvement strategies are required to meet the legislation, guidelines and sustainability criteria referred to under (a).

4. Costs and potential of sustainable ethanol production: The impact of the application of improvement strategies on the

\footnotetext{
${ }^{2}$ Indirect impacts are generated throughout the supply chain, by sub-contractors or suppliers to the organisations that are directly involved in the production, transport and processing of the energy crops. Induced impacts include various (direct and indirect) effects through the displacement of agricultural activities by sugarcane production and/or through the re-spending of income from bioenergy production.
}

costs (per unit; as a result of changes in management of sugarcane or ethanol production) and potential (quantity; as a result of a change of the area or yield of sugarcane production) of ethanol production are quantified as far as possible.

5. Synthesis: The procedure outlined in Table 2 is used to determine to what extent an area of concern is a bottleneck for a sustainable and certified ethanol production.

Four aspects are included: (1) Importance of the area of concern, which is evaluated taking into account the severity of the impact which is determined by looking at the impact on the ecosystem or on human welfare and based on an assessment of the frequency of which an aspect is mentioned in the literature as an area of concern. (2) The availability of indicators and criteria. (3) The necessity of improvement strategies, which is determined by taking into account the difference between the situation that is achieved and the desired situation and the availability of improvement strategies. (4) The impact of improvement strategies on the costs and potential of ethanol production. Each aspect is valued and given a corresponding point, following the division in Table 2. For example, if water pollution is identified as an important environmental problem, than it is classified as 'high importance' and given three points. The sum of the points of the four aspects determines the conclusion to what extent an area of concern is a bottleneck for certification, whereby three levels are distinguished: minor (the sum is 4-6), medium (7-9 points), and major (10-12 points). In the discussion, specific attention is given to gaps in knowledge and future research needs required for the further development of a practically applicable ethanol certification system.

\section{Results}

In this section results are presented for each of the 17 areas of concern. The results are given for ecological (Section 3.2) and socio-economical areas of concern (Section 3.3). Results that are applicable to multiple areas of concern are shown separate (Section 3.4). The impact of compliance with various sustainability criteria on the costs of ethanol is analysed in Section 4 .

\subsection{The ethanol production chain}

Sugarcane is planted using cane cuttings. Its maintenance includes the application of herbicides, pesticides and fertili- 
zers (mineral fertilizers and nutrient-rich wastes from ethanol production). Once planted, a stand of cane can be harvested several times, until the declining yields justify replanting. Sugarcane is harvested by hand or mechanically. Before manual harvesting cane burning is applied. Cane burning is the burning of the leaves and stalk tops of the cane to reduce the costs of harvesting and transportation. In the mill, the sugarcane is washed, chopped, shredded, mixed with water and crushed. The sucrose containing juice is converted into alcohol using yeast (this process is called fermentation) after which purification and distillation takes place. The fibrous waste is burned to generate steam and electricity for the process, but also surplus electricity is generated. For further details see Refs. $[17,18]$.

\subsection{Ecological areas of concern}

\subsubsection{Water use}

Local water shortages occur in SP resulting from the combination of water demanding sectors (mainly agriculture, industry and electricity generation) and water polluting sectors (mainly households and industry) [19,20]. For the production of ethanol ${ }^{3}$ two water use categories are relevant, which are irrigation for cane production and industrial water use for ethanol production. The evapotranspiration (ET) of precipitation by sugarcane is generally not perceived as an important contributor to local water shortages for two reasons. First, the ratio between rainfall and ET is favourable: in the Paraná-Paraguai water basin, which covers most of SP, precipitation is $2140 \mathrm{mmyr}^{-1}$ and ET $1657 \mathrm{mmyr}^{-1}$ [19]. However, during the autumn and winter, which are relatively dry, the ET is higher than the rainfall. Irrigation is not required during this period, because the plants reduce vegetative growth and start to accumulate sucrose (this period is therefore essential for achieving high sucrose levels). A second reason is that the ET is difficult to control except for changing the type of vegetation, but differences are limited. It should also be noted that the ET is generally lower in cropland compared to grassland or natural vegetation, but this impact can be compensated by an increase of runoff. Further, no overview is available of local water shortages in SP. Aggregated at a state level indicate that the contribution of ethanol production to the total water use (excluding ET of precipitation) is limited to $\leqslant 5 \%$ in 2003 (Table 3) and thus also the contribution of ethanol production to water shortages is limited. Yet, the peak of ethanol production is during the relatively dry winter and which indicates that the impact of industrial water use using winter should be analysed.

Irrigation $^{4}$ is generally not economically feasible and is not applied, except in the dryer areas in West SP [21]. In these areas irrigation is expected to increase as a result of the increase in cane production. The industrial water collection (or water intake) may change due to the doubling of ethanol

${ }^{3}$ In this article the term 'production of ethanol' sometimes excludes and sometimes includes the production of sugarcane, depending on the context.

${ }^{4}$ The term irrigation as used in this article excludes fertiirrigation, which is the application of nutrient-rich wastewater to sugarcane fields.
Table 3 - The average water use and supply in São Paulo (in $\mathrm{m}^{3} \mathrm{~s}^{-1}$ ) in 1990 and 2003

\begin{tabular}{|c|c|c|c|c|}
\hline & \multicolumn{2}{|c|}{$1990^{\mathrm{a}}$} & \multicolumn{2}{|c|}{$2003^{b}$} \\
\hline & $\mathrm{m}^{3} \mathrm{~s}^{-1}$ & $\%$ & $\mathrm{~m}^{3} \mathrm{~s}^{-1}$ & $\%$ \\
\hline \multicolumn{5}{|l|}{ Supply } \\
\hline Reference & 2105 & $\mathrm{~N} / \mathrm{a}$ & 2020 & N/a \\
\hline Minimum available flow & 888 & $\mathrm{~N} / \mathrm{a}$ & 893 & N/a \\
\hline \multicolumn{5}{|l|}{ Use } \\
\hline Urban & 97 & 27 & 151 & 39 \\
\hline Irrigation sugarcane $\mathrm{e}^{\mathrm{C}}$ & 8 & 2 & 5 & 1 \\
\hline Irrigation other $\mathrm{crops}^{c}$ & 146 & 40 & 97 & 25 \\
\hline Industry—mills & 47 & 13 & $17^{\mathrm{d}}$ & $4^{\mathrm{d}}$ \\
\hline Industry—other industry & 65 & 18 & 120 & 31 \\
\hline Total & 363 & 100 & 390 & 100 \\
\hline \multicolumn{5}{|c|}{$\begin{array}{l}\text { N/a = not applicable. } \\
\text { a State Plan on Water Resources (PERH) 1994-1995 in [8], and own } \\
\text { calculations. } \\
\text { b State Plan on Water Resources (PERH) 2004-2007 in [8], and own } \\
\text { calculations. } \\
{ }^{c} \text { According to Matoli [21] almost all sugarcane produced in SP is } \\
\text { grown without using irrigation. The water use for the irrigation of } \\
\text { sugarcane and other crops is calculated here assuming that } 5 \% \text { of } \\
\text { total water use for irrigation is used for sugarcane irrigation. } \\
\text { d Calculated based on the water use for mills reported for } 1990 \text {, } \\
\text { corrected for the increase in ethanol production in SP from } \\
7.8 \mathrm{Mm}^{3} \text { in } 1990-1991 \text { to } 8.8 \mathrm{Mm}^{3} \text { in } 2003-2004 \text { [1], and the decrease } \\
\text { in water collection rate from } 5.6 \mathrm{~m}^{3} \mathrm{t}^{-1} \text { cane in } 1990 \text { to } 1.8 \mathrm{~m}^{3} \mathrm{t}^{-1} \\
\text { cane in } 2005 \text { (see Table } 4 \text {; for } 2004 \mathrm{we}^{-1} \text { assumed } 1.8 \mathrm{~m}^{3} \mathrm{t}^{-1} \mathrm{cane} \text { ). }\end{array}$} \\
\hline
\end{tabular}

production projected between 2005 and 2015 [3] and increases in the water use efficiency, see Table 4. If the mid-term target formulated by the Cane Technology Centre of $1.0 \mathrm{~m}^{3} \mathrm{t}^{-1}$ cane is reached in 2015, than the total industrial water collection for ethanol production increases by 11\% between 2005 and 2015.

These data show that industrial water collection rates can be reduced significantly, particularly by increasing the water recycling rate or by replacing wet cane washing by dry cane washing [22,23].

The SP state law 7.633 (1991) provides the basis for legislation (2000, bill 676) that promotes efficient water use based upon the "user-payer" and "pollutant-payer" principle: the user and polluter pay dependent on the amount and quality of the water collected and released. This applies to irrigation and industrial water use, but excludes underground waters and rivers that originate and finish within the boundaries of SP. A committee that includes a.o. representatives from the agricultural sector sets the price of water. Anecdotic information indicates that under pressure from the agricultural sector there are cases where the price of water was set at a level that does not or hardly affect the economic performance of crop production. In these cases the payments can be insufficient to cover the costs of investments in and maintenance of water infrastructures [24].

Based on the information above, more strict criteria seem desired in addition to compliance with the local legislation. 
Table 4 - The water collection, consumption and release from ethanol production in 1990, 1997, and 2005 and various water collection, consumption, and release targets found in the literature (in $\mathrm{m}^{3} \mathrm{t}^{-1}$ cane $\left.\mathrm{yr}^{-1}\right)^{\mathrm{a}}$

\begin{tabular}{|c|c|c|c|c|c|}
\hline 1990 & 1997 & 2005 & $\begin{array}{c}\text { Mid-term target, } \\
\text { Cane } \\
\text { Technology } \\
\text { Centre (CTC) }\end{array}$ & $\begin{array}{l}\text { Minimum target, } \\
\text { World Bank } \\
\text { pollution } \\
\text { prevention } \\
\text { handbook }\end{array}$ & $\begin{array}{c}\text { Achievable target, } \\
\text { World Bank } \\
\text { pollution } \\
\text { prevention } \\
\text { handbook }\end{array}$ \\
\hline 5.6 & 5.1 & $1.8^{\mathrm{c}}$ & 1.0 & $\mathrm{~N} / \mathrm{d}$ & $\mathrm{N} / \mathrm{d}$ \\
\hline 3.8 & 4.2 & $\mathrm{~N} / \mathrm{d}$ & 0 & 1.3 & 0.9 \\
\hline 1.8 & 0.9 & $\mathrm{~N} / \mathrm{d}$ & 1.0 & $\mathrm{~N} / \mathrm{d}$ & $\mathrm{N} / \mathrm{d}$ \\
\hline
\end{tabular}

Various effective improvement strategies are available to reduce the water use and also practically applicable indicators and criteria are available. The increasing use of irrigation in West SP and the large volumes of water involved justify that specific attention is given to the potential impacts of irrigation in the future.

\subsubsection{Water pollution}

Water pollution in SP is a serious, but regional problem. The main cause is the discharge of raw sewage and industrial wastes. A well-studied problem area is the Piracicaba river basin in SP, which is a traditional industrial and agricultural area, and also an important cane-producing region [20,25-27]. No information is available about the exact contribution of ethanol production to water pollution. In this article the two most important types of pollutants from ethanol production are discussed, which are organic pollutants and agro-chemicals. ${ }^{5}$

3.2.2.1. Organic pollutants. Table 5 shows the wastewater flows including the pollution potential and commonly used treatment technologies. In total some $21 \mathrm{~m}^{3}$ water $\mathrm{t}^{-1}$ cane is used, but the net discharge rate is much lower due to recycling (see Table 4 ).

In the past (1970s and 1980s), the uncontrolled discharge of wastewater on surface waters and on land resulted in severe environmental degradation. Presently, most liquid wastes are used for ferti-irrigation, which is the application of nutrientrich wastes on sugarcane fields. Ferti-irrigation application rates (expressed in $\mathrm{m}^{3} \mathrm{ha}^{-1}$ ) have gradually decreased during

\footnotetext{
${ }^{5}$ Also desinfectants (e.g. formaldehyde and various biocides) are used in ethanol production to avoid microbial contamination [23]. Data about the quantities of desinfectants and the types and the environmental impacts are not available, but the limited attention that is given to this issue in the literature suggests that the impact is small. The use of desinfectants can be avoided by using steam or less toxic alternatives.
}

the past decades, to reduce environmental degradation and to optimize the use of nutrients, see also Section 3.2.5.

Legislation includes a water use and discharge pricing system, which is presently being implemented in SP, but which seems inadequate in some cases as already discussed. Other relevant legislation includes standards for ferti-irrigation (see Section 3.2.5), and wastewater emission standards. However, the wastewater emission standards in Brazil are not as strict as other standards, although the differences seem limited (Table 6). Special attention must also be given to the risk of plant breakdowns, which in the past have resulted in the release of heavily contaminated water $\left(\mathrm{BOD}_{5}>18,000 \mathrm{gl}^{-1}\right.$ [28]).

3.2.2.2. Agro-chemicals. An effective disease, pest and weed control is crucial because without yield losses of more than $80 \%$ can occur in cane production [8]. Agro-chemicals are commonly used, but in limited quantities per hectare when compared to conventional crops ( $-40 \%$ compared to corn and more than $-90 \%$ when compared to coffee, citric or soybean [8]). Nevertheless, case studies indicate that the use of agrochemicals is an important contributor to water pollution in areas with a lot of cane production $[26,27]$. A crucial aspect in pest and disease control is the development of resistant cane varieties. Weed growth prevention includes the use of green covers, crop rotation and adequate crop plant spacing. Herbicide resistant weeds in sugarcane production have not been found so far, but the fast increase in herbicide resistant weeds in other crops indicates that this may change [29].

Brazilian legislation defines which agro-chemicals are allowed. It seems that some chemicals are allowed that are presently banned in the EU, such as atrazine [30,31]. For agrochemicals several frameworks exist that formulate further restrictions, such as various global conventions on chemicals (e.g. the Stockholm Convention on Persistent Organic Pollutants [32]) and various guidelines (e.g. the International Code of Conduct on the Distribution and Use of Pesticides [33]).

We conclude that in addition to compliance with legislation in Brazil more strict criteria seem required. Indicators and 
Table 5 - The wastewater flows in sugarcane mills (before recycling) that produce ethanol and sugar on a 50/50 basis (in $\mathrm{m}^{3} \mathrm{t}^{-1}$ cane), the pollution potential, and treatment ${ }^{\mathrm{a}}$

\begin{tabular}{|c|c|c|c|c|}
\hline $\begin{array}{l}\text { Wastewater } \\
\text { type }\end{array}$ & $\begin{array}{l}\text { Volume } \\
\left(\mathrm{m}^{3} \mathrm{t}^{-1}\right. \\
\text { cane })\end{array}$ & Pollution potential ${ }^{\mathrm{b}}$ & Treatment & Remark \\
\hline $\begin{array}{l}\text { Cane washing } \\
\text { water }\end{array}$ & 5 & $\begin{array}{c}\text { Organic matter } \\
\left(180-500 \mathrm{mgl}^{-1} \text { BOD }_{5}\right) \\
\text { and high concentration } \\
\text { of TSS }\end{array}$ & $\begin{array}{c}\text { Settling ponds and pH } \\
\text { adjustment in case of reuse } \\
\text { (closed circuit); settling ponds, } \\
\text { stabilization ponds (open circuit) }\end{array}$ & $\begin{array}{l}\text { Tendency to be } \\
\text { discontinued or replaced } \\
\text { by dry cleaning systems }\end{array}$ \\
\hline $\begin{array}{l}\text { Barometric } \\
\text { condenser } \\
\text { water }\end{array}$ & 6 & $\begin{array}{c}\text { Organic matter } \\
\left(10-40 \mathrm{mgl}^{-1} \mathrm{BOD}_{5}\right) \text { and } \mathrm{T} \\
\text { ca. } 50^{\circ} \mathrm{C}\end{array}$ & $\begin{array}{l}\text { Cooling pond (closed or open } \\
\text { circuit) to bring } \mathrm{T}<40^{\circ} \mathrm{C} \text {; } \\
\text { recirculation and release }\end{array}$ & $\begin{array}{l}\text { The circuits are being } \\
\text { closed aiming zero } \\
\text { leakage system }\end{array}$ \\
\hline $\begin{array}{l}\text { Fermented } \\
\text { cooling water }\end{array}$ & 3 & $\mathrm{~T}$ ca. $50^{\circ} \mathrm{C}$ & $\begin{array}{l}\text { Cooling pond or tower (closed or } \\
\text { open circuit); recirculation and } \\
\text { release }\end{array}$ & $\begin{array}{l}\text { The circuits are being } \\
\text { closed aiming zero } \\
\text { leakage system }\end{array}$ \\
\hline $\begin{array}{l}\text { Distillation } \\
\text { condenser } \\
\text { water }\end{array}$ & 4 & $\mathrm{~T}$ ca. $50^{\circ} \mathrm{C}$ & $\begin{array}{l}\text { Cooling pond (closed or open } \\
\text { circuit) }\end{array}$ & $\begin{array}{l}\text { The circuits are being } \\
\text { closed aiming zero } \\
\text { leakage system }\end{array}$ \\
\hline \multicolumn{5}{|c|}{$\begin{array}{l}\text { Sources: Neto, } 1996 \text { in Refs. [8,145]. } \\
\text { a Data exclude wastewater from plant breakdowns that can result in heavily contaminated wastewater flows with a } \mathrm{BOD}_{5} \text { of up to } 18 \mathrm{gl}^{-1} \text {. } \\
\mathrm{b}^{\mathrm{b}} \text { For the pollution potential of wastewaters from ethanol production four indicators are commonly used, which are the: } \\
\text { - Biochemical oxygen demand (BOD; in } \mathrm{gl}^{-1} \text { ) for determining the oxygen-consuming organic material. The BOD is the main parameter of any } \\
\text { treatment of wastewaster polluted with biodegradable/oxidizable substances. The BOD } \mathrm{B}_{5} \text { is the quantity of oxygen in } \mathrm{mgl}^{-1} \text { that is consumed by } \\
\text { microorganisms at } 20^{\circ} \mathrm{C} \text { within a degradation time of } 5 \text { days. } \\
\text { - Total suspended solids (TSS; in } \mathrm{gl}^{-1} \text { ) for establishing the total quantity of suspended matter (primarily inorganic substances from cane and } \\
\text { beet washing water). } \\
\text { - Acidity }(\mathrm{pH}) \text { as extreme } \mathrm{pH} \text { changes are harmful to water flora and fauna. } \\
\text { - Temperature }\left(\mathrm{T} \text {; in }{ }^{\circ} \mathrm{C}\right) \text { as high temperatures are harmful to water flora and fauna. }\end{array}$} \\
\hline
\end{tabular}

Table 6 - Comparison of Brazilian wastewater emission standards with various (inter) national standards

\begin{tabular}{|c|c|c|c|c|}
\hline $\begin{array}{l}\text { Country or } \\
\text { organization }\end{array}$ & $\begin{array}{c}\mathrm{TSS} \\
\left(\mathrm{mgl}^{-1}\right)\end{array}$ & $\begin{array}{c}\mathrm{BOD}_{5} \\
\left(\mathrm{mgl}^{-1}\right)\end{array}$ & $\mathrm{T}\left({ }^{\circ} \mathrm{C}\right)$ & $\mathrm{pH}(-)$ \\
\hline Brazil & $1.0^{\mathrm{a}}$ & 60 & $\leqslant 40$ & $5.0-9.0$ \\
\hline USA & - & - & - & $6.0-9.0$ \\
\hline UNEP & $20-30^{b}$ & $20-30^{b}$ & - & - \\
\hline World Bank & 50 & 50 & $\Delta \mathrm{T} \leqslant 3^{\mathrm{c}}$ & $6.0-9.0$ \\
\hline \multicolumn{5}{|c|}{$\begin{array}{l}\text { See also Table 5. Sources: GTZ [23], World Bank [22], UNEP [146]. } \\
\text { a In } 1 \mathrm{~h} \text { measures using an Imhoff Sediment Cone. This number } \\
\text { cannot be compared directly with data from other sources } \\
\text { presented in this table, because of difference in definition. } \\
\mathrm{b} \text { The lowest number refers to the secondary treatment limits and } \\
\text { the highest to the advanced treatment limit. } \\
{ }^{c} \text { The effluent should result in a temperature increase of no more } \\
\text { than } 3^{\circ} \mathrm{C} \text { measured at the edge of the zone where the mixing and } \\
\text { dilution takes place. Where the zone is not defined, use } 100 \mathrm{~m} \text { from } \\
\text { the point of discharge. }\end{array}$} \\
\hline
\end{tabular}

criteria to be used are available from legislation and/or certification systems. Effective improvement technologies are available to reduce the emission of organic pollutants, such as recycling and the (aerobic) bacteriological treatment of wastewaters. The additional costs of wastewater treatment in combination with recycling are estimated at $€ 0.03 \mathrm{I}^{-1}$, equal to an increase of $8 \%$ [34]. Pollution from agro-chemicals can be reduced in various ways, e.g., integrated pest management, replacement by less toxic alternatives, or by using biological pest control and manual/mechanical weed control. The use of agro-chemicals can also be avoided completely as the production of organic cane shows (Table A4).

\subsubsection{Biodiversity}

The impact of sugarcane production on biodiversity is analysed using the area under natural vegetation cover and the value of the biodiversity of these areas as a proxy, ${ }^{6}$ whereby two impacts can be distinguished: (1) the direct impact, which is the conversion of natural vegetation into sugarcane plantations) and (2) the indirect or induced impact, which is the replacement of natural vegetation by sugarcane via a shift in agricultural land use that is induced by the use of land for cane production. These impacts are sometimes also referred to as leakage. Because induced impacts of sugarcane production within SP can occur outside SP the geographic scope in this section is extended from SP to Brazil.

Sugarcane production in Brazil accounts for $0.6 \%$ of the total land area or $2.0 \%$ of the agricultural areas [11]; for SP

${ }^{6}$ We thereby ignore other impacts, such as the (negative) impact of the use of agro-chemicals used in sugarcane production, and the (positive) impact of the reduction in greenhouse gas emissions and consequently climatic change resulting from the replacement of fossils. This approach is in line with existing certification systems. 


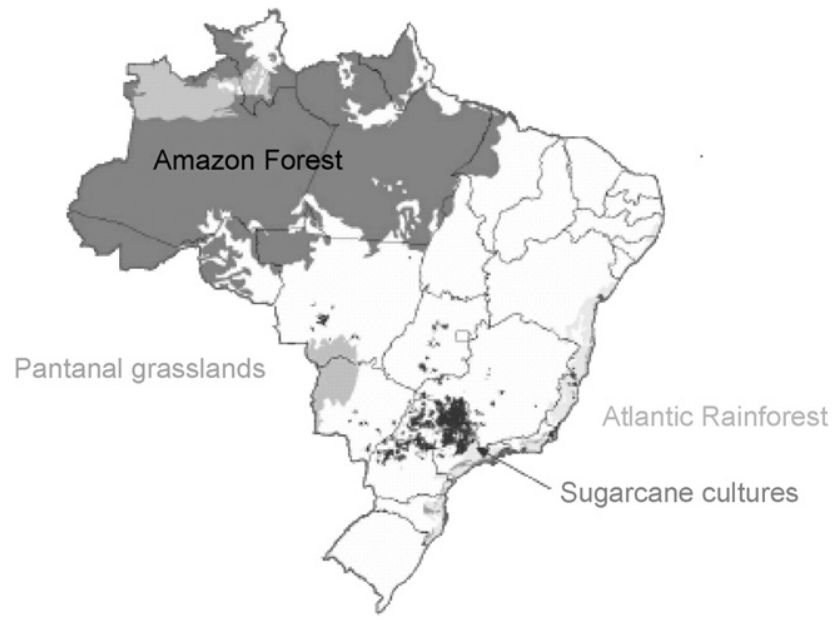

Fig. 1 - The location of sugarcane cultivation and the most important biomes in Brazil. (Data exclude cane production from the North and North-east, for which no data were available. Their contribution of the North and North-east is ca. $15 \%$.) Source: Macedo [8].

these numbers are $18 \%$ and $22 \%$, respectively [35]. The direct and induced impact is likely limited, because the increase in cane cultivation during the previous decades occurred mainly at the expense of agricultural land (pastures and cropland). Further most of the increase took place far away from the most important biodiversity hotspots (Fig. 1). ${ }^{7}$ Data about the direct impact on less important biomes are not available. One important biome not shown in Fig. 1 is the cerrado (savannah), which is located relatively close to the main sugarcane production area in Centre-South Brazil (Fig. 3). ${ }^{8}$ The increase in ethanol production projected for the coming decade will lead to the expansion of cane production in SP, but partially also in areas close to and within the cerrado (Figs. 2-4). ${ }^{9}$ Fig. 4 depicts the three phases of ethanol production expansion specifically for export. The author states that region 1, which partially overlaps with the cerrado that are presently used for extensive cattle raising, is ideal for expansion on the short term, which is in line with Fig. 3 and with the analysis of Sparovek et al. [39]. Region 2 is adequate for expansion in the medium term (excellent location for exports, but competition with eucalyptus plantations) and region 3 is suitable for expansion on the long term. ${ }^{10}$

7 These areas are called hotspots because of the threat to, and the wide diversity of, related endemic species [36].

8 The cerrados host some 10,000 plant species, 195 mammal species, 607 bird species, 225 reptile species, 186 amphibian species, and 800 fresh water fish species and are one of South America's most important biodiversity reserves [37].

${ }^{9}$ Of the original total cerrado area of $204 \mathrm{Mha}$, some $50 \mathrm{Mha}$ is presently used for cattle grazing and 14 Mha for crop production (Bressan, 2000 in Macedo [8]). In all, 70 Mha are potentially suitable for cane production [38].

${ }^{10}$ The central region is now used for pasture and soybeans production and is adequate for sugarcane production without irrigation; the east side is close to the lake of the Sobradinho dam, along the Sao Francisco River-despite high productivity potential, irrigation will be necessary.
At this moment $25 \%$ of the cerrado receives some form of protection [37], which is insufficient to prevent conversion of undisturbed cerrado into agricultural land. The agricultural land area increased from 249 Mha in 1993 to 264 Mha in 2003 [40]. The increase in cane production could contribute to a continuation of this process, directly or indirectly. The doubling of the land prices in the West SP resulting from the strong demand for land for cane production is an indicator of increasing pressure on the remaining land resources [41].

There is no planning of sugarcane production in SP or Brazil [42]. However, there are various sections of legislation that affect the availability of land for this production, particularly the forest code (FC). The FC requires each land owner to maintain a proportion of each property under natural vegetation as a legal forest reserve ( $20 \%$ in SP), but many land owners are out of compliance with the legal reserve obligation [43]. Recently, landholders are allowed to satisfy the requirement for one property through a legal forest reserve located on another (2001, Decree 2166-67). The FC also designated areas close to rivers and water streams as Permanent Preservation Areas (PPA), which means that these areas must be maintained in, or restored to their natural state. PPA overlap with less than $1 \%$ of the sugarcane area, so this PPA legislation will hardly affect cane production [8].

The data above indicate that direct impacts can be avoided by requiring that sugarcane production is restricted to areas previously used for crop production or cattle grazing, up to a certain number of years ago. This criterion will most likely have a limited impact on the availability of land for cane production, because the expansion of cane production takes place mainly on agricultural land. The indirect and induced impacts, i.e. an increase in cane production within existing agricultural land leads to the conversion of natural vegetation to agricultural land, are potentially important, but are more difficult to tackle, because these impacts are difficult to quantify and practically applicable indicators are presently not available. Potential indicators are the price of land, the area under cane production, the area under natural vegetation and the species diversity of specific areas. Indirect and induced impacts can be avoided by defining a maximum cane production area or by increasing the efficiency of food production to free land for sugarcane production. In theory up to half of the agricultural land used in 1998 can be made available for energy crop production in Brazil in 2015, taking into account increases in food consumption, by increasing the productivity $[15,44]$, see also Section 3.3.1. However, most scenarios indicate that under current conditions increases in production efficiency are much lower, resulting in a continuation of the conversion of natural areas into agricultural land at a rate of $1.8 \mathrm{Mha} \mathrm{yr}^{-1}$ during the coming decade [45], compared to an agricultural area in 2003 of 264 Mha [40].

\subsubsection{Soil erosion}

Soil erosion in sugarcane production is generally limited compared to the production of conventional agricultural crops such as corn and soybeans, although the difference is dependant on local conditions (e.g., the slope gradient, rainfall pattern, harvesting system). Soil erosion rates of sugarcane areas found in the literature range widely, depending on the slope gradient, 


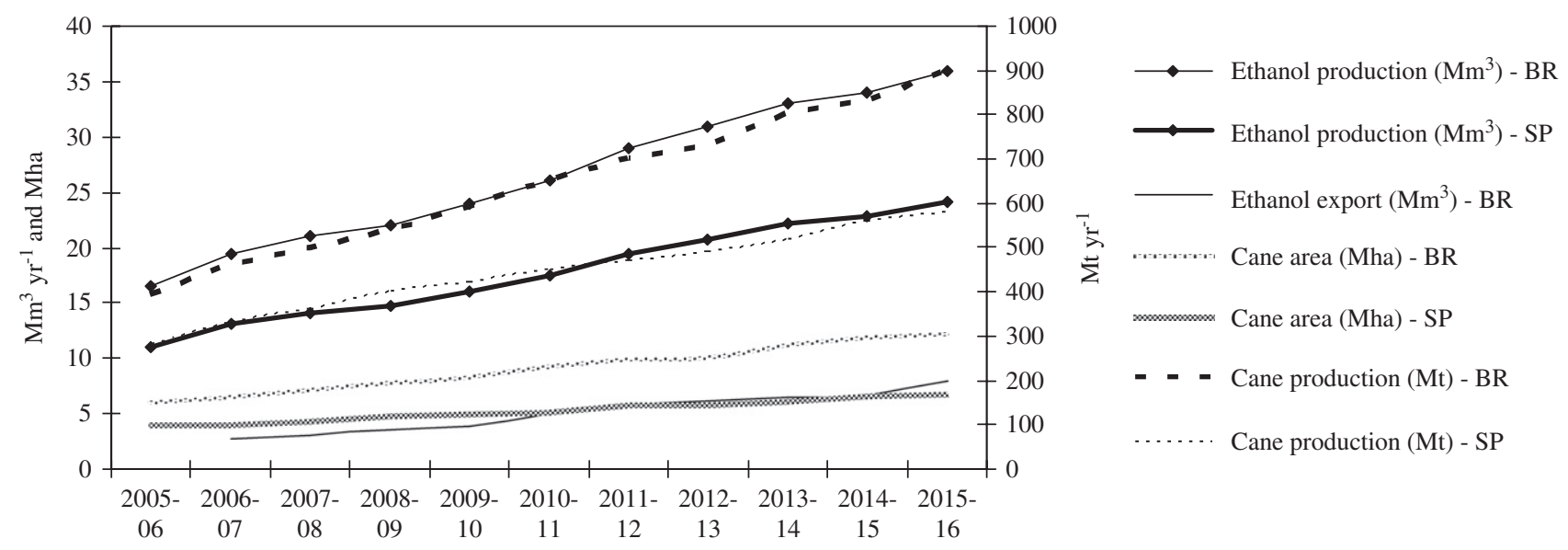

Fig. 2 - Projected increase in cane production (in $\mathrm{Mt} \mathrm{yr}^{-1}$ ), cane area (in Mha), ethanol production (in $\mathrm{Mm}^{3} \mathrm{yr}^{-1}$ ) between 2005 and 2016 in Brazil and SP and projected increase in ethanol exports in Brazil between 2005 and 2016. Sources: [3,13,137]. Data from $[3,13]$ have been estimated from graph. The production of ethanol in SP is estimated by assuming that two-third of the ethanol in 2005-2006 is produced in SP [1] and assuming that the ethanol production increases linearly with cane production. This approach most likely underestimates the ethanol production in SP by excluding increases in ethanol yield and increases in the cane sugar content. Other projections found in the literature are: $640 \mathrm{Mt}$ sugarcane in Brazil in the year 2013 [118], $25 \mathrm{Mm}^{3}$ ethanol production in Brazil in 2015 and $4.6 \mathrm{Mm}^{3}$ ethanol export from Brazil in 2015 [138], $26 \mathrm{Mm}^{3}$ ethanol production and $4.4 \mathrm{Mm}^{3}$ ethanol export in 2015 [139]. Fulton (2004 in Ref. [4] foresees an increase of the ethanol production to $21 \mathrm{Mm}^{3}$ in $2010,61 \mathrm{Mm}^{3}$ in 2020,121 Mm $\mathrm{Mm}^{3}$ in 2030 and $310 \mathrm{Mm}^{3}$ in 2050. Johnson [140] estimated the ethanol production of Brazil in 2020 at $62 \mathrm{Mm}^{3}$ (E4 scenario)) plus own calculations.



Fig. 3 - The location of the present sugarcane production areas, the cerrado area and the location of some new mills (dark marks/points) in South-Central Brazil. Sources: modified from [141,142].

length and the soil type, but a median of about $20 \mathrm{tha}^{-1} \mathrm{yr}^{-1}$ is reported (Bertoni et al., 1998 in [8,46-48]). For comparison: the average rate of soil erosion on cropland in the US was $6.7 \mathrm{tha}^{-1} \mathrm{yr}^{-1}$ in 2001 [49] and soil formation rates are generally ca. 2 tha $^{-1} \mathrm{yr}^{-1}$ [48]. The soil erosion rate in the US is lower than in Brazil thanks to the lower rainfall and slope gradients in the US. Pastures generally have a much lower soil erosion rate compared to land used to grow annual crops, roughly a factor 20 or more. Severe soil erosion can negatively affect the suitability of soils for crop production and can also lead to a reduction in the soil C content (see further Section 3.2.8).
There is no legislation aimed specifically at soil erosion. The cane burning phasing out schedule can also reduce the risk of soil erosion if the sugarcane residues are left on the soil, and this is the mid-term tendency in SP. Various guidelines and handbooks are available that focus on the application of soil erosion prevention technologies (best practice management, [50-53]), although these are not specifically aimed at sugarcane cultivation. In some of these documents maximum tolerable soil erosion rates are defined.

Most existing certification systems and guidelines require the application of soil erosion prevention technologies, such 


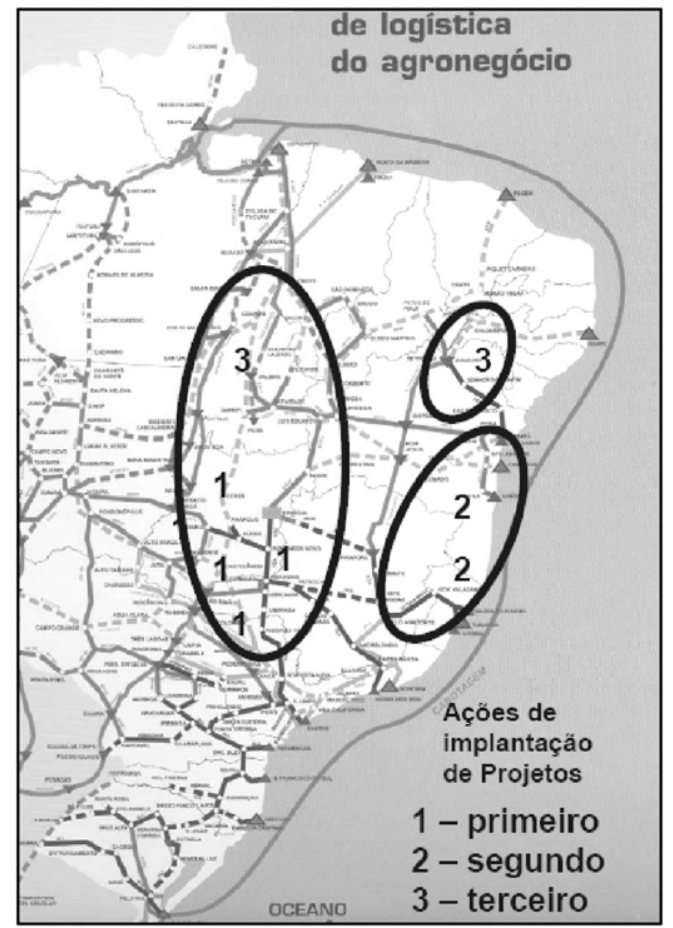

Fig. 4 - The location of areas in Brazil suitable for ethanol production for export, subdivided into areas that are suitable on the short term (1), medium-term (2), and longterm (3). Source: [143].

as contour ploughing, bench terracing, ${ }^{11}$ and mechanical harvesting without cane burning. Indicators and criteria focus on the application of these technologies and/or on soil erosion rates. A substantial level of soil erosion is common in conventional agriculture, including cane production. Thus, more strict criteria seem appropriate, based on e.g. the rate of soil erosion compared to the natural rate of soil formation and the erosion lifetime. ${ }^{12}$ It should be noted that erosion cannot be avoided completely. The (theoretical) costs to reduce soil erosion from $20 \mathrm{tha}^{-1} \mathrm{yr}^{-1}$ to a level equal to the natural rate of soil formation are estimated to increase the production costs of ethanol with $3 \%$.

\subsubsection{Fertilizer use}

Sugarcane is able to use $\mathrm{N}_{2}$ from soil air through symbiosis with bacteria, but is not a leguminous species [55]. Consequently, the mineral fertilizer application rates (in $\mathrm{tha}^{-1} \mathrm{yr}^{-1}$ ) in cane cultivation are lower compared to conventional (non-leguminous) crops [8], but higher compared to pastures. The use of mineral fertilizers in cane production is not identified in the literature as an area of concern and therefore

${ }^{11}$ The combination of bench terracing and mechanical harvesting is however problematic, since harvesting machines cannot cross terraces. Bench terracing increases the manouvring time and may reduce the harvest efficiency $\left(\mathrm{th}^{-1}\right)$ by up to $40 \%$ [54]. In addition, it may be that up to $25 \%$ of the sugarcane area must thus be harvested manually after the mechanical operation. These data stem from the 77 ha Ceveiro watershed located in the south-eastern part of Brazil (Piracicaba water basin).

12 The erosion lifetime is the time it takes before a soil reaches its minimum depth given for a certain land use type. the use of mineral fertilizers is further ignored. More important is the application of nutrient-rich wastes to cane fields (ferti-irrigation), which has both positive impacts (e.g., the reduced need for mineral fertilizers, the higher exchange capacity, the improved structure, the increased water retention capacity), and negative impacts (e.g., the increased risk of salinization and nutrient leaching). The total impact of fertiirrigation in SP is unknown, because only site-specific studies are available. An overview of studies about the impact of fertiirrigation is presented in [8].

Technical standards have been adopted recently in SP regarding ferti-irrigation (2005, standard P4.231). Nowadays it is forbidden to apply ferti-irrigation on sensible areas and technical standards are included for the storage, processing and application of vinasse. A funding programme named Procop (Pollution Control Programme) supports producers in financing investments that are needed to meet these standards. There seems to be a consensus that an application rate of $300 \mathrm{~m}^{3} \mathrm{ha}^{-1}$ has no negative impacts [8], which is higher that the average of $100 \mathrm{~m}^{3} \mathrm{ha}^{-1}$ applied in SP [6].

Compliance with legislation is essential, because of the severe environmental degradation from ferti-irrigation observed in the past. The most important improvement strategy is to reduce/optimize the application rate, which is also used as an indicator and criterion in existing legislation. Additional requirements seem desirable, because existing standards do not require nutrient balances to be used as a basis to determine the optimum application rates.

\subsubsection{Genetically modified organisms}

In 2003 Brazil completed the Cane Genome project, which involved the sequencing of 40,000 cane genes that are related to disease resistance, stress response, nutrient metabolism, etc. Further, the Cane Technology Centre (CTC) has developed transgenic cane varieties, including field trials, but the National Technical Biosafety Committee (CTNBio) withdrew the field trial permits after public concerns about the (potential) ecological impacts of genetically modified organisms (GM organisms or GMOs). Three more years of field tests are required to test the effectiveness of the GM cane and commercial results could be realized after another 2 years [8]. The impacts of GMOs are subject of extensive research and debate. There is no consensus, partially because the ecological impacts of GMOs are dependant on the exact genes that are altered or introduced and uncertainties are high. However, the public opinion in both Brazil and the EU is quite negative [56].

GMOs have been banned in Brazil for a long time, but the illegal plating of GM soybean forced the government to formulate legalization regarding GMOs. It is expected that the present legislation in Brazil will be streamlined and that more GMOs will be approved in the future [57,58]. The Brazilian regulatory framework is similar to the EU model, while the inspection and evaluation procedures follow the US model [56]. No detailed information is available to what extent the Brazilian standards match with EU and US standards. Various certification systems and non-governmental organizations (NGOs) adopt the precautionary principle and reject the use of GMOs, except for traditional applications such as the use of GM yeast in bread production. 
See Refs. [57,58] for an overview and discussion of GMO legislation in Brazil.

Due to a wide range of potential modifications and the scientific uncertainties mentioned above, no generally applicable indicators and criteria can be formulated at this moment, other than a complete ban on GM sugarcane (GMSC). Based on this conclusion and taking into account the negative attitude towards GMOs in the EU and Brazil, it seems wise to apply the precautionary principle and reject the use of GM cane, at least until more information on the impacts is available. In case less strict criteria are formulated, than these should be allowed for a case-by-case specific evaluation of the GM cane varieties.

\subsubsection{Sugarcane burning}

Cane burning has gradually decreased in SP, from $82 \%$ of the harvested area in 1997 to $63 \%$ of the harvested area in 2004. A shift from manual harvesting (which is done with cane burning) to mechanical harvesting (which is generally done without cane burning) has negative and positive impacts, see Table $7 .^{13}$

The recently implemented legislation in SP on cane burning implies that mechanical harvesting without cane burning is the best option. This legislation includes a cane burning phasing out schedule (Table 8) and prescribes how, where and when cane burning is allowed. In 2007 an (voluntary) agreement between the SP state government and cane producer was signed in order to accelerate the phasing out of cane burning. This agreement aims at a stop of cane burning in the year 2016. The implementation of mechanical harvesting is limited by the high investment costs. Also the present status of mechanical harvesting technology and the topographic conditions found in the Centre-South of Brazil is the reason that mechanical harvesting is not fully possible on $40-50 \%$ of the land. These areas can be harvested using semimechanized methods [60]. The most important negative impact of mechanical harvesting is the reduction of employment, see further Section 3.3.3.

A reporting requirement is included in the legislation for cane producers, whereby cane producers are required to specify a cane burning reduction schedule. The legislation specifically takes into account the practical socio-economical consequences, i.e. the high capital costs associated with mechanical harvesting as well as employment effects. In theory, negative employment effects can be compensated, e.g., by adopting a manual harvesting system without cane burning, but such a harvesting system is not widely used because of the high costs.

Most stakeholders agree with a reduction in cane burning [11]. However, the negative employment effects from increas-

${ }^{13}$ Some areas are harvested mechanically after cane burning: in 2002 the fraction of the sugarcane area of all Copersucar associated mills in SP that was burnt and unburnt was $80 \%$ and $20 \%$, respectively, but the fraction of the area that was manually and mechanically harvested was $65 \%$ and $35 \%$, respectively [59]. Thus, some $15 \%$ of the cane fields in SP are burnt and mechanically harvested, assuming that manual harvesting only is applied to burnt cane areas. The reason is that harvesting machines, particularly the old ones, are $30 \%$ more efficient with burnt cane [11].

Table 7 - The advantages and disadvantages of the conversion of manual cane harvesting (including cane burning) to a mechanical cane harvesting (excluding cane burning)

\section{Advantages}

Decrease of the occurrence of poor working conditions associated with manual cane harvesting

Decrease of costs of harvesting

Increase of availability of cane trash $\rightarrow$ increase in energy output to input ratio and greenhouse gas emission reduction when residues are collected and used for electricity generation

Decrease of cane burning emissions

Table 8 - The sugarcane burning phasing out schedule included in São Paulo state law 11,241 from 2000

\begin{tabular}{lcc}
\hline & $\begin{array}{c}\text { Areas where } \\
\text { mechanical } \\
\text { harvesting is possible } \\
\text { (slope gradient }<12 \%) \\
(\%)\end{array}$ & $\begin{array}{c}\text { Areas where } \\
\text { mechanical harvesting } \\
\text { is not possible (slope } \\
\text { gradient }>12 \%)(\%)\end{array}$ \\
\hline 2002 & 20 & - \\
2006 & 30 & - \\
2011 & 50 & 10 \\
2016 & 80 & 20 \\
2021 & 100 & 30 \\
2026 & - & 50 \\
2031 & - & 100 \\
\hline Source: [8]. & & \\
\hline
\end{tabular}

ing the use of a mechanical harvesting system require attention, particularly in case a reduction is demanded in a certification scheme that goes beyond the legal requirements. Specific attention seems also appropriate for cane burning in 


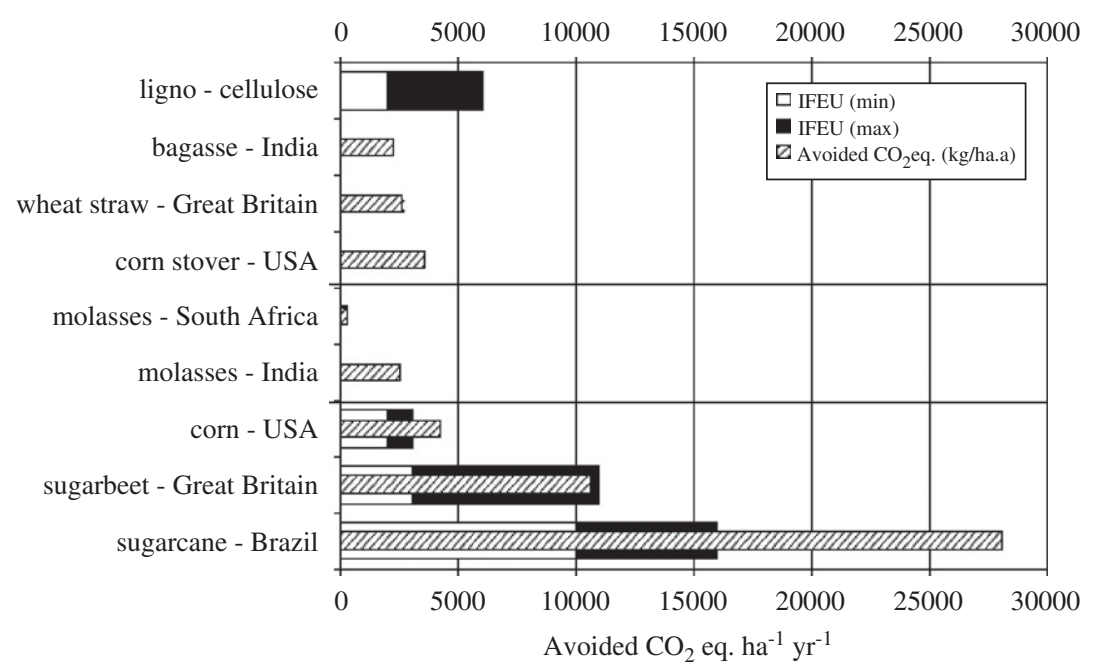

Fig. 5 - The avoided GHG emissions $\left(\mathrm{kg} \mathrm{CO}_{2}\right.$ eq. $\left.\mathrm{ha}^{-1}\right)$ for various biofuels, present situation. IFEU is the Institute for Energy and Environmental Research that has recently completed a review of life cycle studies of biofuels and of which the ranges are included in the figure below. Source: reprinted from Von Blottnitz and Curran [144], with permission from Elsevier.

Table 9 - The technical potential of electricity production by cogeneration from bagasse and barbojo using different technologies for electricity generation and the decrease in the steam demand for ethanol production (kWh electricity per tonne cane)

\begin{tabular}{|c|c|c|c|}
\hline Technology & $\begin{array}{l}\text { Steam demand ethanol } \\
\text { production }\left(\mathrm{kgt}^{-1} \text { cane) }\right.\end{array}$ & $\begin{array}{c}\text { Cogeneration, bagasse } \\
\left(\mathrm{kWh}_{\mathrm{e}} \mathrm{t}^{-1} \text { cane }\right)\end{array}$ & $\begin{array}{c}\text { Cogeneration, barbojo } \\
\text { (kWhe } \mathrm{t}^{-1} \text { cane) }\end{array}$ \\
\hline $\begin{array}{l}\text { 1. Combustion, partial steam extraction } \\
\text { turbine, } 22 \text { bar, }-300^{\circ} \mathrm{C}\end{array}$ & 500 & $0-10$ & 0 \\
\hline $\begin{array}{l}\text { 2. Combustion, partial steam extraction } \\
\text { turbine, } 80 \text { bar, }-480^{\circ} \mathrm{C}\end{array}$ & 500 & $40-60$ & 0 \\
\hline $\begin{array}{l}\text { 3. Combustion, condensing steam } \\
\text { turbine, } 80 \mathrm{bar},-480^{\circ} \mathrm{C}\end{array}$ & 340 & $67-100$ & $33-50$ \\
\hline $\begin{array}{l}\text { 4. Gasification, steam-injected gas } \\
\text { turbine }\end{array}$ & $<340$ & $135-200$ & $65-100$ \\
\hline
\end{tabular}

combination with mechanical harvesting, because this type of harvesting combines the negative impacts of cane burning with the negative employment effect of mechanical harvesting. One option is full compensation of the negative employment effects from a full shift of manual to mechanical harvesting (without cane burning) by means of unemployment benefits. This would increase the production costs of ethanol with $8 \%$ compared to the present situation. The additional costs are expected to decrease in the future due to the cane burning phasing out schedule.

\subsubsection{Greenhouse gas emission and energy balance}

Ethanol produced from sugarcane is more efficient with respect to the replacement of fossil energy and the reduction of greenhouse gas (GHG) emissions when expressed per unit land and when compared to other bioenergy options. Fig. 5 shows GHG reduction compared to other biofuels; the results for lingo-cellulose fuels are based on the use of waste material.

The results for sugarcane are based on a study by Macedo and co-workers, which is one of the three studies about the GHG emissions and energy balances of ethanol production in Brazil [59,61,62], from now on called Macedo, Oliveira and Langer, respectively. A detailed comparison shows that the differences between Macedo/Langer ${ }^{14}$ and Oliveira are caused by differences in the diesel use for agricultural operations, sugarcane yield, ethanol yield, energy consumption of seed production, system boundaries, definitions and harvesting system. In this study the GHG emissions and energy balance of ethanol production in SP are calculated for now and the

\footnotetext{
${ }^{14}$ Langer uses the data and approach from Macedo, except for the system boundaries: long-distance transportation of ethanol for export is excluded in Macedo (and also in Oliveira), but included in Langer.
} 
future (2030+), whereby results are given for different harvesting systems, for various levels of the use of cane residues for electricity production and for four technologies for electricity cogeneration shown in Table 9 [63].

The total amount of electricity sold to the grid increased from 80 GWh in 1997 to 1350 GWh in 2004 in SP is expected to increase further [63]. Technology 1 and 2 (see Table 9) are currently used. Technology 1 is based on the use of bagasse (the fibrous residue left after cane milling), but without the use of barbojo (the tops and leaves). This technology will probably be used for many years to come in particularly small plants. Technology 2, also without the use of barbojo, is presently being implemented and this will reduce the amount of energy required for ethanol production and increase the amount of electricity delivered to the grid. Technology 3, which includes the use of bagasse and barbojo, is commercially available, but is not yet applied. It is expected that technology 4 will be competitive and commercially available after 10 years or more from now [64]. For the presented average situation we assume that $5.9 \mathrm{kWh}$ electricity is cogenerated per tonne cane, on average [63]. In the future higher figures are expected for technologies 2-4, ranging from 40 to $300 \mathrm{kWh}$ electricity per tonne cane, having an impact on the avoided GHG emissions. Ideally, the avoided emissions from electricity cogeneration should be derived from a comparison of the emissions in case of a scenario with and without cogeneration, but such an analysis goes beyond the scope of this paper. Instead, two reference systems are included that represent the boundaries of the avoided emissions per kWh electricity. (1) Electricity generation from the total capacity recently installed in South, South East and mid-West Brazil, which is $87 \%$ non-fossil fuel capacity, for which an emission factor of $109 \mathrm{gCO}_{2}$ eq. $\mathrm{kWh}^{-1}$ is included [65]. Further analysis revealed that these emissions can all be attributed to the capacity that uses fossil fuels. (2) Electricity generation from gas fired capacity, for which an emission factor of $404 \mathrm{~g} \mathrm{CO}_{2}$ eq. $\mathrm{kWh}^{-1}$ is calculated $[66,67]$. The latter options is chosen because the bulk of the increase in installed capacity during the coming decades is expected to come from natural gas $[67,68] .{ }^{15}$ The energy credits from cogeneration are expressed in primary energy from fossil fuels and are calculated assuming a primary energy input of $2.0 \mathrm{kWh} \mathrm{kWh}^{-1}$ electricity for natural gas fired plants, assuming a conversion efficiency of $50 \%$ for natural gas fired combined cycle plants and $0.33 \mathrm{kWh}$ fossil fuel input per $\mathrm{kWh}$ electricity for the average recently installed capacity (recalculated from [65]). Most other data are taken from Macedo, supplemented by data from the literature [70]. Macedo is chosen instead of Oliveira, because Macedo is more detailed and includes more recent data compared to Oliveira, and because the diesel consumption of agricultural operations assumed by Oliveira is overestimated. A detailed comparison of Macedo and Oliveira is shown in Table A1. The input data used in our calculations are presented in Table A2 and the results are shown in Figs. 6 and 7. The results are compared with the results of Macedo, because this is the

${ }^{15}$ Clean Development Mechanism (CDM) projects recently submitted to the UN Framework Convention on Climate Change (UNFCCC) presents an emission factor of $269 \mathrm{~g} \mathrm{CO}_{2} \mathrm{kWh}^{-1}$ [69].

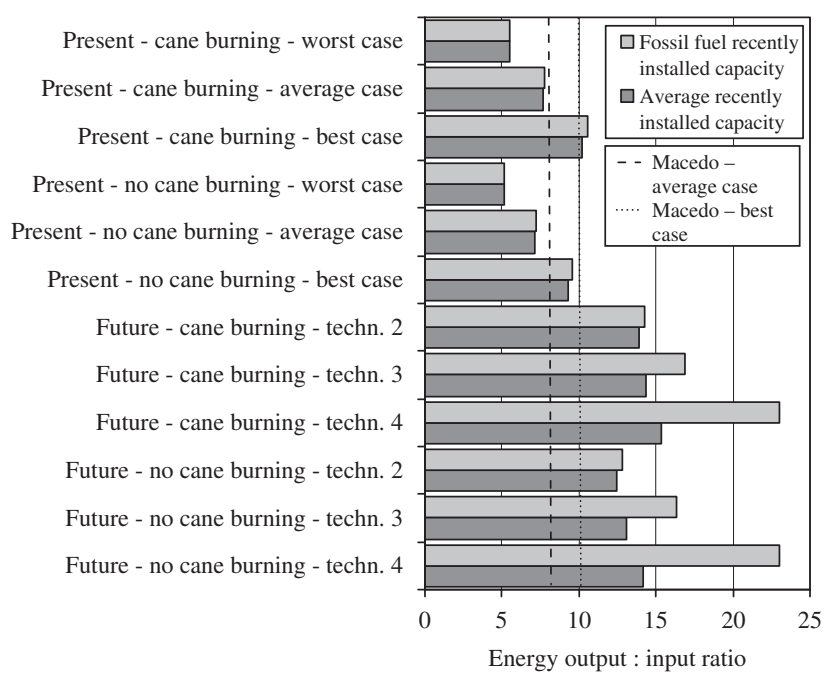

Fig. 6 - The energy balance of ethanol produced from sugarcane in São Paulo in various situations compared to the results of Macedo [59]. Sources: [59,61,70] and own assumptions.

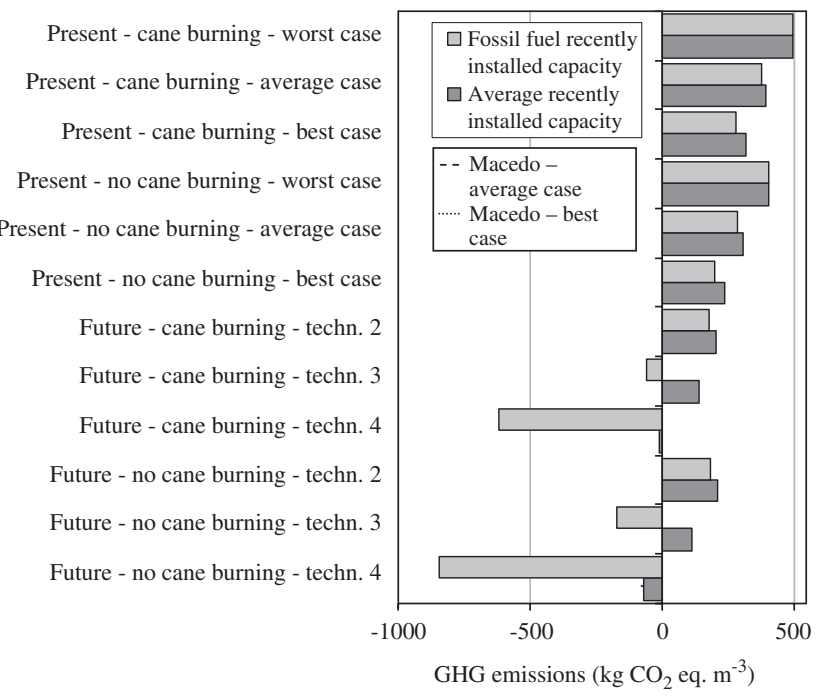

Fig. 7 - The greenhouse gas emissions (in $\mathrm{kg} \mathrm{CO}_{2}$ eq. $\mathrm{m}^{-3}$ ethanol) of ethanol produced from sugarcane in São Paulo in various situations compared to the results of Macedo [59]. Sources: $[59,61,70]$ and own assumptions.

main source that is used in virtually all studies on GHG balances. The results for sugarcane burning are representative for the Centre-South in the year 2002, which means we assume that $80 \%$ of the cane area is burnt, $20 \%$ is not burnt and of the total cane area $35 \%$ is mechanically harvested and 65\% manually [59]. Other input data, assumptions and detailed results are shown in Table A2.

The results show that in Brazil (SP) the present average energy output to input ratio of ethanol production is 7.7-7.8, with a worst-case and best-case bandwidth ranging from 5.5 to 10.3-10.6. These differences are caused by differences in the cane yield (in $\mathrm{tha}^{-1} \mathrm{yr}^{-1}$ ), ethanol yield ( $\mathrm{t} \mathrm{t}^{-1}$ cane), the amount of electricity that is cogenerated, and the choice of 
the reference system. Further increases in cane yield, ethanol yield and in the amount of surplus electricity can increase the ratio to a maximum of $15-23$, depending of the reference system. The amount of surplus electricity depends on the technology (i.e. the amount of energy needed for the production of ethanol and the efficiency of electricity cogeneration) and the availability and use of barbojo for cogeneration (i.e. the harvesting system and the technology). The present greenhouse gas emissions are calculated at $376-396 \mathrm{~kg} \mathrm{CO} 2$ eq. $\mathrm{m}^{-3}$ ethanol), with a range of $498 \mathrm{kgCO}_{2}$ eq. $\mathrm{m}^{-3}$ (worst case; no electricity cogeneration) to between 282 and $321 \mathrm{kgCO}_{2}$ eq. $\mathrm{m}^{-3}$ (best base) depending on the choice of reference system, but can be reduced to a maximum of $-843 \mathrm{kgCO}_{2}$ eq. $\mathrm{m}^{-3}$ in case of technology option 4 (gasification of bagasse and barbojo, electricity cogeneration using a combined cycle) and with full mechanical harvesting without cane burning.

Further, the hydrolysis of bagasse and barbojo and subsequent fermentation can increase the ethanol yield by another $34 \mathrm{tt}^{-1}$ cane, using $30 \%$ of the excess bagasse and $50 \%$ of the barbojo. The hydrolysis of bagasse and barbojo limits the cogeneration of electricity. The net impact on the energy balance and GHG emissions of ethanol production could not be calculated due to a lack of data, but significant decreases in the production costs of ethanol are projected [71].

The data presented above exclude long-distance transportation of ethanol for export. The transportation of the ethanol from the ethanol plant via São Sebastião harbour (SP, Brazil) by ship to Rotterdam harbour (The Netherlands) increases the energy consumption by $2.9 \mathrm{GJ}$ ha. This decreases the energy output to input ratio from 7.7-7.8 to 6.6-6.7 and increases the GHG emissions from $376-396$ (average) to $418-438 \mathrm{~kg} \mathrm{CO}_{2}$ eq. $\mathrm{m}^{-3}$ ethanol, depending on the reference system. Input data for these calculations are derived from Langer [62]. An other important issue not taken into account in the results presented above are the GHG emissions from changes in above- and below-ground biomass, litter, dead wood and soil organic matter from changes in land use that are induced by the production of sugarcane. Detailed data on changes in land use that are induced by sugarcane production are scarce and the same goes for data on the GHG emissions from land use changes. It should be noted that the bulk of the increase in cane production during the period 2002-2004 occurred at the expense of pastures, but the indirect and induced impacts of cane production could also result in the conversion of natural vegetation (Section 3.3.1). Most estimates of changes in organic C stocks from tillage of native cerrado soils are generally in the range of $\pm 10 \%$ or less [72,73], but higher losses have also been reported: Silva et al. [74] reported a decrease of $41-80 \%$. Further, Silveira et al. [75] reported a decrease in soil organic $\mathrm{C}$ of $22 \%$ for the conversion of pasture to sugarcane production in the Piracicaba river basin in SP. The impact of changes in soil organic C on the GHG balance can be large: a 10\% decrease resulting from the conversion of cerrado to sugarcane production equals an emission of $237 \mathrm{~g} \mathrm{CO}_{2} \mathrm{~m}^{-3}$ ethanol or an increase of $63 \%$ compared to the present average situation and assuming an initial $\mathrm{C}$ content of $45 \mathrm{tC} \mathrm{ha}^{-1}$ and a 20 -year period before a new equilibrium $\mathrm{C}$ content is reached. Freitas et al. [76] suggested that the $C$ input from crop residues left on the soil are crucial for maintaining soil $\mathrm{C}$ content. This raises the question whether the GHG emission reductions of increasing the use of barbojo (cane trash) for electricity cogeneration outweigh the (potential) GHG emissions from decreases in the soil C content. Soil erosion is another important driver or decreases in soil $\mathrm{C}$ content [72]. Potentially even more important are changes in above- and below-ground biomass when forests or grassland are converted to sugarcane plantations. The conversion of forests is relevant when considering the indirect impacts. For example, 1 ha of undisturbed tropical moist deciduous forest, which is the native forest type in some parts of SP, equals a carbon stock of $90 \mathrm{t}$ in above-ground biomass [66]. This equals $1112 \mathrm{~kg} \mathrm{CO}_{2} \mathrm{~m}^{-3}$ of ethanol, assuming a 50-year period and assuming that all carbon in the biomass is released as $\mathrm{CO}_{2}$. This would increase the GHG emissions of ethanol production by $280-395 \%$, in the case of the current average situation, assuming as reference for cogeneration of electricity the recently installed total capacity and the recently installed fossil fuel fired capacity, respectively. Yet, the net GHG emissions from changes in biomass, litter, dead wood, and soil organic are zero in case converted areas are converted back into their original state. Similarly, the emissions are very low when the change in $\mathrm{C}$ pool is discounted over longer periods. Considering the potential impact of these issues, further research is urgently required on both the carbon stocks and on the indirect impacts of sugarcane production.

The data above indicate that the energy balance and GHG emissions of ethanol from SP are favourable compared to other biofuels and compared to fossil-based fuels. Consequently, additional criteria are not essential, but they can be useful to stimulate the development and implementation of new technologies, particularly considering the potential large gains. The GHG emissions from changes in above- and belowground biomass, litter, dead wood, and soil organic matter should receive special attention.

\subsection{Socio-economical areas of concern}

\subsubsection{Competition with food production}

Eight per cent of the population in Brazil was undernourished in 2001-2003 [77], which is mainly the result of poverty and less the result of lack of production capacity. The incidence of undernourishment in SP is likely lower, because the average income in SP is higher than in the rest of Brazil. The growth of sugarcane production for the production of ethanol could compete with the production of food, ${ }^{16}$ which could threaten the food supply security. The availability of productive land is a key limiting factor as the area of agricultural land is not allowed to increase to avoid negative impacts on biodiversity (see further Section 3.2.3). Competition for other production factors is probably of less importance. However, it should be noted that Brazil is a major food exporter and it is expected that the export of food will increase rapidly during the coming decades [78]. This increase will be supplied from increases of

\footnotetext{
${ }^{16}$ The issue of competition also goes for other issues, e.g. wood and cotton. Here we focus on food production, although the conclusions are also applicable for the competition with other functions.
} 
the area of agricultural land at the expanse of natural vegetation and increases of the productivity. In theory, further increases in productivity are achievable with simultaneous decreases in the area of agricultural land required for food production to roughly half the present area of agricultural land [15], but such a development is probably not realistic under the current and projected economic conditions [44]. Recently, Sparovek et al. [39] presented an expansion model that is feasible at current market conditions and that involves the use of hydrolysed bagasse as an animal feed. This could reduce the migration of ranchers to remote regions, such as the cerrado, but could also reduce the use of the cerrado for cattle raising. However, an obstacle for large-scale implementation of this system is the competition with the use of bagasse for heat and electricity generation. Further, the bulk of the increase in cane production in SP during the period 2002-2004 occurred mainly at the expanse of land used for cattle grazing (SMA 2005 in [79]). The increase in cane production in southeast Brazil during the 2005-2006 harvest season caused a reduction of the production of tomato, peanut, and oranges in SP [80] and a reduction in coffee plantation in Minas Gerias, Espírito Santo, and SP [81]. The doubling in land prices in West SP between 2002 and 2005, which is an important sugarcane expansion area, also suggests an impact on food prices [41]. Indirect positive impacts on food security, e.g. through the generation of additional income have not been investigated yet. Further, there is a direct correlation between ethanol production and sugar production, since many mills produce both sugar and ethanol: the sugar to ethanol production ratio depends on the price of sugar and ethanol. Scenario studies of the OECD indicate a price of white sugar in 2014 of $100 \epsilon_{2005} \mathrm{t}^{-1}$ in the constant biofuels scenario that assumes no additional biofuel production compared to the present price of $200 \epsilon_{2005} \mathrm{t}^{-1}$. In the policy-target scenario, which assumes that biofuel production develops according to stated national goals, the price is projected to increase to $160 \epsilon_{2005}$ in 2014 or $188 \epsilon_{2005} \mathrm{t}^{-1}$ in case of a continued high oil price of 60 US\$ per barrel is assumed that increases the costs of production but also increases the demand for bioethanol [82]. A further liberalization of the OECD sugar markets could also have a major impact on the sugar price and thereby ethanol price; Mitchell [83] estimated that full trade liberalization would increase the sugar costs by $40 \%$. A further analysis of these dynamics goes beyond the scope of this study. Also, it should be noted that sugar crops accounted for only $18 \%$ of the daily food intake in Brazil in 2004 [40].

Additional research is required to assess the total net (direct and indirect) impact of ethanol production on food security in SP and to develop suitable criteria and indicators. Possible indicators are: the food intake, food purchasing power, food prices, and land use patterns. Potentially useful tools to analyse and monitor the impact of large-scale sugarcane production on food production at a macro-level are: input-output (I/O) analysis, social accounting matrix (SAM) analysis, and food equilibrium modelling, but such analysis have not yet been carried out and need further evaluation. Further, research has shown that the efficiency of food production in Brazil, expressed in output per unit land, is well below what is (theoretically) agro-ecologically feasible: the area required for food production in 2015 can be limited to half the 1998 area [15,44]. This implies that (in theory) the production of food can be increased without expanding the area of agricultural land used for food production. How such a transition can be achieved has been poorly studied yet.

We conclude that especially poverty is currently a major bottleneck for food security, much more than a lack of production means like land or labour due to the production of sugarcane. However, competition for land between (the increasing production of sugarcane and food could become a bottleneck, particularly because the conversion of (semi-) natural vegetation to agricultural land is unsustainable. Positive impacts via a.o. employment may compensate for the negative impacts, but insufficient data are available to assess the net impact of ethanol production.

\subsubsection{Land tenure}

Data in the literature indicate that land tenure is an important problem in general in Brazil, where landless people are a major group of rural poor. Historic data suggest that existing legislation is insufficient and too weak to protect small farmers and to prevent disputes over land issues. Particularly the position of small farmers is problematic. During the 1970s and 1980s the expansion of sugarcane production exacerbated land tenure conflicts. Cases have been reported whereby farmers have been forced off their land by legal or economic pressure, or by direct physical intimidation (Saint, 1982 in Ref. [84]). Exact and more recent data are however not available. Yet, the increasing cane production has likely a limited negative or even positive impact on land tenure conflicts, because the issue of land reform is less important in SP where commercial agriculture is a well-established activity [85]. Also it must be noted that most conflicts are at present in the Amazon region [86]. For land tenure and property rights there is sufficient legislation, but we do not analyse this further because of the complexity of the issue and because various studies indicate that law enforcement is the main issue and not lack of legislation.

It can be concluded that in SP land tenure conflicts due to sugarcane production are at present a limited problem. Also these conflicts can be tackled using criteria, indicators and tools from existing certification systems [51,52]. Existing certification systems generally focus on the documentation related to these issues, e.g. property ownership, land use contracts, and minutes of meetings with land owners.

\subsubsection{Employment}

Unemployment is a major problem in São Paulo and solving this problem is a key priority. The production of sugarcane and ethanol is an important source of employment in SP. Three employment effects can be distinguished:

- Direct: employment generated in the sugarcane and ethanol production sectors.

- Indirect: employment generated in the industries that produce intermediate deliveries to the sugarcane and ethanol production sectors.

- Induced: employment generated or lost due to the induced effects of sugarcane and ethanol production, e.g. the 
Table 10 - Direct employment in sugarcane and ethanol production in São Paulo in 1992 and 2003, divided into formal and informal jobs $(\times 1000)$

\begin{tabular}{|c|c|c|c|c|c|c|}
\hline & \multicolumn{3}{|c|}{1992} & \multicolumn{3}{|c|}{2002} \\
\hline & Formal & Informal & Total & Formal & Informal & Total \\
\hline Sugarcane & 149 & 36 & 185 & 124 & 16 & 140 \\
\hline Ethanol & $\mathrm{N} / \mathrm{d}$ & $\mathrm{N} / \mathrm{d}$ & $\mathrm{N} / \mathrm{d}$ & $\mathrm{N} / \mathrm{d}$ & $\mathrm{N} / \mathrm{d}$ & $33^{\mathrm{a}}$ \\
\hline Total & $\mathrm{N} / \mathrm{d}$ & $\mathrm{N} / \mathrm{d}$ & $\mathrm{N} / \mathrm{d}$ & $\mathrm{N} / \mathrm{d}$ & $\mathrm{N} / \mathrm{d}$ & 173 \\
\hline
\end{tabular}

$\mathrm{N} / \mathrm{d}=$ no data

Sources: the Administrative Records of the Labour and Employment Ministry (RAID) and National Household Sample Research (PNAD) databases in [8].

${ }^{a}$ Calculated by multiplying the total employment in sugarcane production by the ratio total formal employment in ethanol production to total formal employment in sugarcane production in 2002 in Central-South Brazil.

Table 11 - Employment in cane production in 1997 and after the introduction of fully mechanised harvesting

\begin{tabular}{lccc}
\hline Region & Employment 1997 ( $\times 1000)$ & $\begin{array}{c}\text { Employment after } \\
\text { mechanisation }(\times 1000)\end{array}$ & $\begin{array}{c}\text { Employment reduction }(\% \text { of } \\
1997)\end{array}$ \\
\hline North & 2.0 & 0.2 & 90 \\
North-east & 225.9 & 76.3 & 66 \\
Mid-west & 35.7 & 11.0 & 69 \\
South-east & 194.7 & 95.3 & 51 \\
South & 52.3 & 11.5 & 78 \\
Total Brazil & 510.7 & 194.4 & 62 \\
& \\
\hline
\end{tabular}

change in employment in case sugarcane production replaces food production and the employment generated as a result of the increase in income spending and consequently production.

Recent and accurate data are only available about the direct employment (Table 10).

Table 10 shows that there has been a strong decrease in employment in the sugarcane sector, which is the result of the increase in mechanical harvesting in sugarcane production. One harvesting machine replaces up to 100 workers [87]. Guilhoto et al. (2002 in Ref. [11]) suggest that mechanization is possible in approximately $50 \%$ of the north-eastern areas and in $80 \%$ of the rest of the country, which could reduce the direct employment in cane production by 52-64\%. Table 11 shows the impact of mechanized harvesting compared to 1997. The positive employment effect from the use of trash for energy is estimated to compensate the negative employment effect for just 7\%. Another source estimated the potential to reallocate the work-force released by mechanical harvesting at $20 \%$ [88].

Yet, the indirect and induced impacts can be more important than the direct impacts: Guilhoto (2001 in Ref. [8]) estimated the ratio between direct, indirect and induced jobs in Brazil in the late 1990s at 1:1.4:2.8. Note that it is not clear what the definition of induced impacts is, thus it may exclude the impact of the replacement of food production. The latter type of induced effects is positive in case of the replacement of livestock production (employment per hectare in sugarcane is a factor 9 the average employment in livestock production). Presently, the labour intensity of sugarcane is roughly the same as for other crops. ${ }^{17}$

The formulation of criteria is hampered by a lack of accurate data about the total net employment effect: the (in)direct impact is positive, but the induced effect could be both positive and negative. Various tools can be used to calculate the total net employment effects at a macroeconomic level of an increasing ethanol production (e.g., I/O analysis, SAM, equilibrium modelling), but these need to be further developed and evaluated. Using I/O analysis, Scaramucci and Cunha [90] calculated that the impact of an expansion of ethanol production by $800 \%$ in Brazil, which is equal to $5 \%$ of the global demand for gasoline in the year 2025 , may increase the GDP by $11 \%$. Also more than 5 million jobs would be created in case cane production is fully mechanized.

\footnotetext{
${ }^{17}$ Calculated based upon the following data: in 20039.063 million people were employed in the agricultural sector in Brazil, of which 0.484 million in sugarcane production [8]. In 2003 the area used for the production of arable land and permanent crops was 66.6 Mha and the area permanent pastures was 197 Mha [40]. The labour intensity of livestock production is on average a factor 10 lower compared to crop production [89].
} 
Table 12 - The average income, age, years of education, and Gini coefficient for all people occupied, or engaged, in the sugarcane culture and similar industries in Brazil and SP in 2003

\begin{tabular}{|c|c|c|c|c|c|c|c|}
\hline & \multicolumn{2}{|c|}{ Sugarcane crops } & \multirow[t]{2}{*}{ Sugar } & \multirow[t]{2}{*}{ Ethanol } & \multirow{2}{*}{$\begin{array}{l}\text { Foods and } \\
\text { beverages }\end{array}$} & \multirow[t]{2}{*}{ Fuels } & \multirow[t]{2}{*}{ Chemicals } \\
\hline & Brazil & SP & & & & & \\
\hline People $(\times 1000)$ & 489 & 130 & 126 & 67.0 & 1507 & 105 & 641 \\
\hline Mean age (years) & 35 & 36 & 37 & 35.6 & 34 & 37 & 33 \\
\hline Mean education (years) & 2.9 & 4.2 & 6.5 & 7.3 & 7.1 & 8.9 & 9.6 \\
\hline Mean income $\left(\epsilon_{2003} \text { per month }\right)^{a}$ & 139 & 247 & 255 & 264 & 178 & 397 & 333 \\
\hline Gini coefficient $(-)$ & 0.493 & 0.565 & 0.423 & 0.393 & 0.490 & 0.476 & 0.531 \\
\hline
\end{tabular}

Table 13 - The average income (in $€ /$ month) and years of education for all people occupied, or engaged, in the production of different crops in Brazil and São Paulo in 2003

\begin{tabular}{|c|c|c|c|c|c|c|c|c|c|c|}
\hline Region & Statistic & Unit & Rice & Banana & Coffee & Sugarcane & Citrus & Manioc & Corn & $\begin{array}{l}\text { Soy } \\
\text { bean }\end{array}$ \\
\hline \multirow[t]{2}{*}{ Brazil } & Income & $€_{2003}$ per month ${ }^{a}$ & 99 & 108 & 111 & 139 & 152 & 68 & 66 & 324 \\
\hline & Education & Year & 2.3 & 3.1 & 3.6 & 2.9 & 3.8 & 1.8 & 2.3 & 4.9 \\
\hline \multirow[t]{2}{*}{ São Paulo } & Income & $€_{2003}$ per month ${ }^{a}$ & $\mathrm{~N} / \mathrm{d}$ & 140 & 197 & 247 & 181 & $\mathrm{~N} / \mathrm{d}$ & 192 & 268 \\
\hline & Education & Year & $\mathrm{N} / \mathrm{d}$ & 3.9 & 5.5 & 4.2 & 4.8 & $\mathrm{~N} / \mathrm{d}$ & 3.9 & 5.8 \\
\hline
\end{tabular}

\subsubsection{Income distribution}

A commonly used indicator to express income distribution is the Gini coefficient. ${ }^{18}$ Brazil has one of the highest Gini coefficients in the world (the higher the Gini coefficient, the higher the differences in income): 0.58. For comparison, the Gini coefficient in the US and the EU25 is 0.41 and 0.32 , respectively [91]. The Gini coefficients of the sugarcane and ethanol production sector is lower compared to the national average and compared to various other sectors (Table 12).

Income differences within the sugarcane and ethanol sector are lower than the average Gini coefficient of Brazil (0.58). Income differences in sugarcane production are relatively high (the Gini coefficient is 0.57 ); the spread in income is smaller within the ethanol production sector, which has a Gini coefficient of 0.39 . We conclude that only in case strict criteria are applied higher wages for low-income workers are required to reduce these differences. The additional costs of increasing wages would be limited: e.g.

${ }^{18}$ The Gini coefficient is often used to measure income inequality. It is defined as a ratio: the numerator is the area between the Lorenz of the income distribution and the uniform income distribution line; the denominator is the area under the uniform income distribution line. The Lorenz curve depicts the cumulative distribution of income. The value of the Gini coefficient is between 0 and 1 . A value of 0 corresponds to perfect equality (everyone has the same income) and 1 corresponds to perfect inequality (one person has all the income, and everyone else has zero income). an increase of the wages of cane harvesters by $50 \%$ would increase the costs of ethanol by $4 \%$ (see Section 4 ).

\subsubsection{Wages}

Tables 12 and 13 show the average wage in the sugarcane and ethanol sector compared to other sectors in 2003.

These data indicate that the average wage in sugarcane production in SP is generally higher compared to the production of other crops; the same goes for the average wage in the ethanol sector compared to other industries. Average wages in 2003 were above the nominal minimum wage of $74 €$ per month [92]. In the calculation of this figure a conversion rate of $0.31 € \mathrm{R} \$^{-1}$ was assumed for the year 2003 [93]. Because of wide regional variations in the cost of living, the government has no official poverty line. Yet, wages earned may still be insufficient to allow a decent standard of living: the Interunion Department of Socioeconomic Studies and Statistics (DIEESE) calculated a 'net minimum wage necessary' ${ }^{19}$ for a family of four to be ca. 4.6 times the minimum wage, assuming one wage earner within this family [92]. The

\footnotetext{
19 The minimum wage necessary is defined according to a constitutional precept as: "the minimun wage set by law, unified around the country, able to supply basical and vital familliar, such as housing, food, education, health, leisure, clothes, hygiene, transportation, social security, and is periodically updated to preserve the power of purchasing" (Brazilian Constitution, Chapter II, Social Rights, Article 7).
} 


\section{Table 14 - The number of total workers (adult and child workers) and child workers (defined here as workers under the age} of 18) in sugarcane production in Brazil in 2002

\begin{tabular}{|c|c|c|c|}
\hline Statistic & $\begin{array}{l}\text { Workers (adult and } \\
\text { child) } \times 1000\end{array}$ & $\begin{array}{l}\text { Child } \\
\text { workers } \times 1000\end{array}$ & $\begin{array}{l}\text { Percentage child workers to total workers } \\
\text { (\%) }\end{array}$ \\
\hline Total in agriculture & 29,860 & 2418 & 8.0 \\
\hline $\begin{array}{l}\text { Total in the sugarcane } \\
\text { sector }\end{array}$ & 415 & $23^{a}$ & 5.5 \\
\hline
\end{tabular}

Bolsa Familia (Family Stipend), which provides a financial aid to poor families, defines extreme poverty as $\leqslant 0.7$ times the minimum wage and poverty at $70-140 \%$ of the minimum wage (for a family of four and assuming one wage earner) [94]. An average cane cutter earns 1.8 times the minimum wage during a maximum of 8 month harvesting season and this equals 1.2 times the minimum wage after reallocation over the entire year. There are however cases of temporary workers that had to pay unrealistically high costs for transportation, housing and food and there are cases of workers that were paid less than previously agreed upon [95].

Wages are a practical and easy to verify indicator. Compliance with the legal minimum wage is obviously a minimum requirement, but higher wages seem desirable to prevent poverty or to ensure a decent living standard. Improvement strategies include an increase of wages, increase expenditures on, e.g., health care, housing, and social benefits (see also Section 3.3.8). As noted before, if the wages of the unskilled labour used in harvesting would increase with an arbitrary $50 \%$, than the total costs of ethanol would increase $4 \%$ (see Section 4).

\subsubsection{Working conditions and worker rights}

The literature review indicates that poor working conditions are associated mainly with manual cane harvesting. Temporary migrant workers employed in cane cutting in SP, who often do not have working documents, are probably the most vulnerable group [95], although wages are a factor 1.8 higher than the minimum wages. A major cause is the high workload in combination with poor health care, inadequate diet and lack of protective equipment. Mechanized cane harvesting has become a reference for the quantity cut by the workers and consequently the workload increased from $6 \mathrm{t}$ in the 1980 s, to $10 \mathrm{t}$ in the $1990 \mathrm{~s}$, to $12-15 \mathrm{t}$ today in some cases (amount of sugarcane cut per day per worker). The repetitive movements of cane cutting cause tendinitis and spinal column problems, loosening of the digits and spasms, provoked by the excessive loss of potassium. Frequent spasms followed by dizziness, headache, and vomiting are called "birola". In total 14 cases of immediate deaths from cane cutting have been reported in the 2004-2005 and 2005-2006 harvest season in Brazil, all young migrant workers (Pastoral do Migrante, in [11]). Cane cutting is also associated with cancer, provoked by sugarcane soot and also by the use of agro-chemicals, the latter caused some 700 cases of poisoning and 15 deaths in 1998 [96]. ${ }^{20}$ Other health problems are respiratory illnesses, allergies and spinal column illnesses. Worst-case examples of poor working conditions include cases in which mills required the sterilization of female cane cutters and cases of slavery [95].

Local legislation seems in principle sufficiently strict to ensure proper working conditions and also allows free organization into networks of protection (unions, land and migrant pastoral agencies, and other). However, the information presented above indicates that compliance with legislation is often lacking and law enforcement is weak. Existing legislation and law enforcement strategies can be used to formulate criteria and indicators, whereby compliance with existing legislation must be a key issue.

\subsubsection{Child labour}

The Labour and Employment Ministry of Brazil collect data about the formal labour market. These data indicate that in 2002 in the Centre-South of Brazil 1261 children between 15 and 17 years old were employed in the sugarcane sector and 67 in the ethanol sector [8]. For children between 10 and 14 years old these figures were 13 and 2, respectively [8]. These numbers are equal to $0.4 \%$ and $0.1 \%$ of the total formal employment in the case of children between 15 and 17 years old and $<0.01 \%$ and $<0.01 \%$ for children aged $10-14$. The occurrence of child labour in ethanol production (including sugarcane production) in the whole country is calculated to be $<0.01 \%$ for children aged between 10 and 14 years and $0.3 \%$ for children aged 15-17. These numbers exclude informal labour and thus the total occurrence of child labour is higher: the number of children between 10 and 17 years old that is involved in sugarcane production in Brazil is estimated to be 23,000 [98], see also Table 14 . This equals $5.5 \%$ of the total number of workers involved in the production of sugarcane and $3.0 \%$ of the total number of workers involved in sugarcane plus ethanol production. We assume that the number of children working at the processing of cane to ethanol is very low, because child labour is associated with simple manual labour, while the production of ethanol is

\footnotetext{
${ }^{20}$ Calculated based on the total number of casualties from the application of agro-chemicals, of which some $6.5 \%$ is used for cane production $[96,97]$.
} 
industrialized and requires mostly skilled labour. The total occurrence of child labour in Brazil is 6.3 million [98].

These data indicate that child labour is a widespread phenomenon in Brazil, but also that child labour in sugarcane and ethanol production is limited compared to other agricultural activities. Since the data on child labour do not distinguish between the types of job, the extend to which the employment of children under 18 can be categorized as undesirable child labour is not determined, i.e. labour done by children under the age of 18 that prevents them from going to school (getting an education), or that is dangerous or unhealthy. ${ }^{21}$ The Brazilian legislation is in line with the internationally accepted standards of the International Labour Organisation (ILO): the (official) minimum working age is 16 years, except for apprenticeships. Further, work is forbidden for all minors under the age of 18 when the work constitutes a physical strain or when it concerns a.o., nocturnal, unhealthy or dangerous conditions, which include cane harvesting. Detailed information about age restrictions, job types, and exceptions can be found in text of ILO convention 138 (1973) and 182 (1999) [99]. However, law enforcement is weak: child labour inspections are not carried out on a regular basis; they are driven by complaints brought by workers, unions, NGOs, and the media [100]. Further, inspections are mainly focussed on the informal sector. In case of violations, inspectors attempted to reach agreements to have employers desist from labour law violations before levying fines. As a result, few employers are fined for employing children [100]. Various certification systems are available that include practically applicable indicators and criteria [52].

We conclude that additional criteria seem appropriate to ensure that the legal requirements are met, using existing certification systems. The (theoretical) costs to prevent child labour by means of compensating parents for the loss of family income from child labour and by means of compensating parents for the costs of education is calculated to increase the ethanol costs by $4 \%$ (see Section 4 ).

\subsubsection{Social responsibility and benefits}

Table 15 shows results of a survey of social benefits of sugarcane and ethanol production based on a sample of 47 mills in SP [101].

Further, the industry in Brazil adopted in 2002 the Social Balance Sheet (SBS) concept, which gives an overview of key parameters on education, health care, profit sharing programmes, and so on. Some of the SBS-indicators and their values in 2003 are presented in Table 16 for 73 SP-based companies. The results show that the benefits are at present very modest.

For migrant workers without official papers these benefits may not be available at all. In addition, the figures above provide no information on the quality of these services of the quality of life in general of the workers in the sugarcane and ethanol industry. Further information can be derived from the

${ }^{21}$ There is no universally accepted definition of child labour. The definition of child labour as used in this article is derived from the International Labor Organization (ILO) Worst Forms of Child Labour Convention (ILO convention 182) [99].
Table 15 - Social benefits given by mills to workers ( $\%$ of the mills that provides the social benefit), based on a sample of 47 mills in SP in 2003

\begin{tabular}{lc}
\hline Type of social benefit & \% Of mills \\
\hline Health care & 96 \\
Dental care & 94 \\
Transportation & 93 \\
Collective life insurance & 92 \\
Meals & 87 \\
Pharmaceutical care & 85 \\
Hearing care & 64 \\
Funeral allowance & 62 \\
Christmas basket & 59 \\
Food basket & 44 \\
Credit cooperative & 38 \\
Club/association & 36 \\
Education allowance & 36 \\
Other & 33 \\
Food stamps & 30 \\
Private pension plans & 24 \\
Breakfast & 21 \\
Disease allowance & 20 \\
Loan/financing & 15 \\
Agreement with supermarkets & 9 \\
Subsidized sales & 2 \\
Consumption cooperative & 0 \\
\hline Source: Ref. [101]. & \\
\hline
\end{tabular}

Table 16 - Indicators in the Social Balance Sheet for 73 mills in SP in 2003 (expenses as percentage of payroll)

\begin{tabular}{lc}
\hline Type of social benefit & Expenses as \% of payroll \\
\hline Private pension plan & 0.8 \\
Health care & 5.9 \\
Education & 0.9 \\
Capacity building & 1.0 \\
Day-care units & 0.3 \\
Profit-sharing programmes & 6.7 \\
Food & 6.5 \\
Occupational safety and health & 2.3 \\
& \\
\hline Source: IBASE (2004) in [8]. & \\
\hline
\end{tabular}

literature and from various databases, such as the Human Development Indicators (HDI) of the World Bank, but these sources are not further discussed here because of the wide range of issues that they include. Further research is required to identify issues that require additional attention. For the development of practically applicable criteria and improvement strategies the Bolsa Familia (Family Stipend) and similar programmes can be helpful. ${ }^{22}$

Legislation is not discussed here, because of the wide range of issues included and resulting very large amount of associated laws. Further, the data are insufficiently detailed to determine which areas (e.g., education, health care, and

22 Other programmes are the Bolsa Escola (school allowance), Bolsa Alimentação (Food Allowance), Cartão Alimentação (Food Card), and Auxílio Gás (Gas Allowance). 
pensions) require additional attention. In further research the various areas should be analysed separately. However, based on the limited information that is available, social responsibilities and benefits seem to be of less importance than the issue of, e.g. wages and child labour.

\subsection{Multidisciplinary issues}

For many multidisciplinary issues location-specific data are available. Often these data provide no information about the final situation or result, such as the species diversity or the health of the workers. Using available data is an approach that is also applied in existing certification systems, which formulate criteria based on practically measurable indicators. This approach is understandable because of the complexity and uncertainties related to assessing the final impact starting from site-specific, practically measurable indicators and criteria for which data are available. We conclude that the inclusion of criteria that focus more on the final situation or result compared to the practically usable criteria than are included in existing certification systems could in theory offer a higher level of certainty that an area of concern is effectively about the coverage of an issue of concern, but could in practice be problematic.

The scope of our analysis is limited to the direct impacts of sugarcane and ethanol production because of practical reasons, with the exception of biodiversity, competition with food production, and employment. We thereby ignore indirect and induced impacts, such as changes in land use and changes in household expenditures for which data are usually not readily available. This approach is in line with existing certification systems. We conclude that if indirect and induced impacts should be included than the formulation of practically usable criteria and indicators becomes more difficult.

In the previous sections only legislation and guidelines directly relevant to the area of concern is discussed. However, various laws are applicable to several issues. An example is the Environmental Crimes Law (1998, law 9605), which includes penalties for both direct and indirect negative economical and social impacts. Penalties are determined based on the nature, intensity and reversibility of the impact, taking into account local conditions. The Brazilian law also states that a license to produce sugarcane and ethanol can be obtained only after environmental impact study is carried out and a corresponding report is presented to prevent negative impacts on the physical environment (atmosphere, land, and water), the biotic environmental (flora and fauna), and the atrophic environment (jobs, economic, and socio-cultural aspects). Licences are required for both installation and operation. In SP operating licences must be renewed every 2-5 years.

Law enforcement in Brazil is generally weak and consequently many mills are out of compliance with existing environmental and labour legislation [6,102]. Consequently, compliance with existing legislation should be a key issue in any international certification system and would eradicate many of the worst-case situations. This goes particularly for child labour, poor working conditions, and various types of environmental pollution.
Various criteria, guidelines, and standards presented in the literature can be helpful for the further development of a certification system. Examples are the 'Pollution Prevention and Abatement Handbook' of the World Bank [22], the 'Environmental Handbook' of the German Corporation for Technical Cooperation [23], and the 'Code of Practice for Sustainable Cane Growing' [103]. These sources include guidelines and standards specifically for ethanol production. Also relevant are various sections of the 'Cane Sugar Handbook: A Manual for Cane Sugar Manufacturers and Their Chemists' [104]. Particularly the 'Sugarcane and Ethanol Environmental Management Method' that was developed by Borrero et al. [105] seems useful. This method measures the environmental performance, but also deals with social and economic aspects related to the level of employment and productivity. Nineteen performance categories are distinguished, for which 66 parameters are formulated. For each parameter three performance classes are distinguished: low, average, and high, including criteria. This method has been applied to three mills in SP and the results show a significant improvement of the environmental performance during the study period 1987-1997. Further, in 2002 a multi-stakeholder team developed the 'Principles and General Criteria for Social and Environmental Certification Imaflora/ SAN of the Sugarcane Culture' [106], which is a practically applicable set of environmental and socio-economic standards for sugarcane production. This set has not been applied (yet), basically as a result of lack of interest from the industry and politics [107]. Further, the Fairtrade Labelling Organizations International (FLO) has developed standards for socially and environmentally responsible production and trade, including specific criteria from sugar made from sugarcane [108]. Then there is the World Wildlife Foundation initiative called Better Sugarcane Initiative (BSI), which is a multistakeholder collaboration whose mission is to improve the environmental and social impacts of sugarcane production and processing [109]. The BSI also is developing criteria and standards for sustainable cane production. The Ethanol and Sugar Impact Analysis (ESIA) label is another example of a recent initiative aimed at developing standards and criteria [110].

In addition, various a-specific criteria, guidelines and standards are potentially useful. Examples are the Global Reporting Initiative (GRI), which aims to develop generally applicable reporting principles (including performance indicators) for different environmental and socio-economical areas of concern [111]. Also the Social Accountability (SA) 8000 standards for decent working conditions, which are based on ILO and UN conventions, can be useful [112]. It goes beyond the scope of this study to evaluate the usefulness of all these and other systems; see Lewandowski and Faaij [12] and Van Dam and Faaij [113] for an overview of relevant certification systems and recent developments.

\section{Economic implications}

In Brazil the production costs of hydrated ethanol decreased from $0.87 €_{2005} l^{-1}$ in 1975 to $0.26 €_{2005} l^{-1}$ in 2004 [114]. The production costs are currently below that of any other liquid biofuel. Ethanol is at present, on average, competitive with 


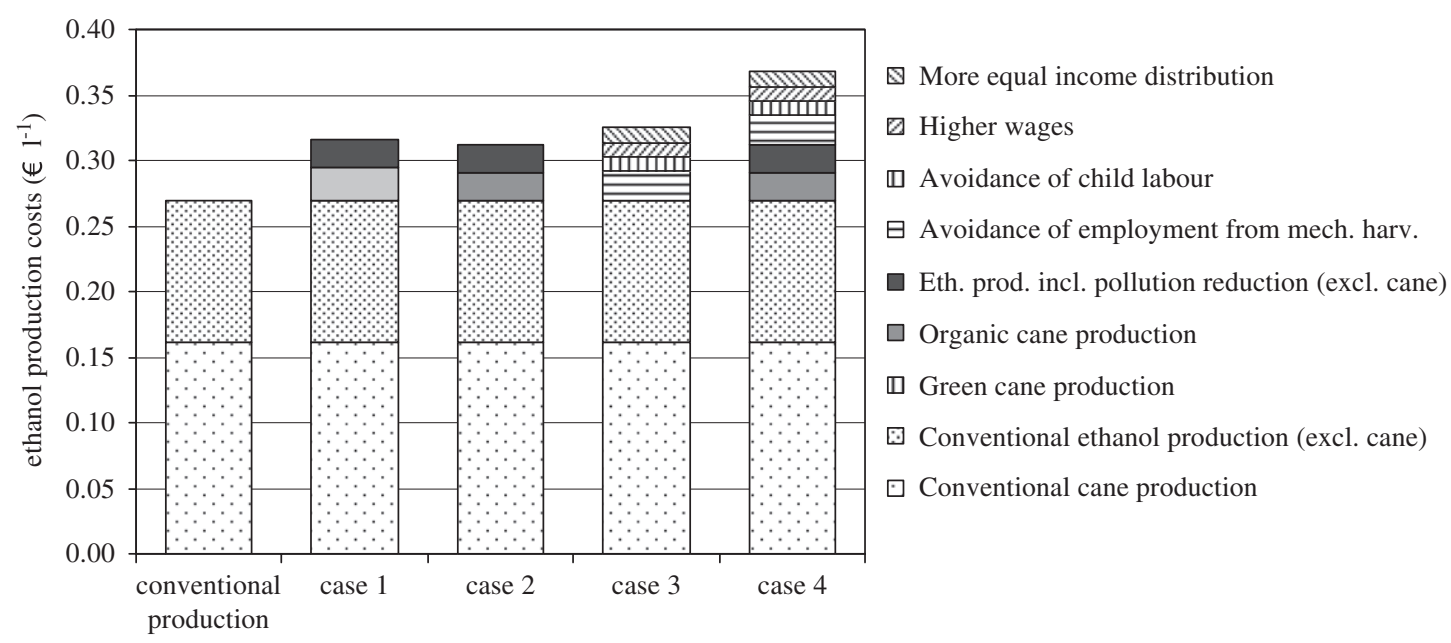

Fig. 8 - The costs of ethanol production taking into account the costs of compliance with various sustainability criteria as calculated for 4 cases in comparison to the present costs of conventional ethanol production in São Paulo (These costs exclude the costs of long-distance ethanol transportation, which would increase the costs of ethanol by $2 \epsilon_{2005} 1^{-1}$ [6]) (in $€_{2005} \mathrm{l}^{-1}$ ). See also text and Table A3.

gasoline and diesel from fossil oil at an oil price of 40-50 US\$ per barrel, which is the case since 2003 [115]. Government control, such as quotas for production and export, as well as subsidies for production and logistics have been completely abandoned since 2002, with the exception of the mandatory $20-26 \%$ volume of ethanol in gasoline sold at the pump. Compliance with sustainability criteria increases the production costs of ethanol, which are calculated for four cases:

1. The production of ethanol from green cane, which includes the application of best management practice. This includes full mechanical harvesting (no cane burning) and reduced tillage and compliance with all social, technical, and environmental legislation, including a reforestation programme. The increase in costs presented here is based on the relative increase of cane production costs similar to the São Fransisco mill in SP, which is the largest producer of organic and green cane in Brazil, see further Table A3.

2. The production of ethanol from organic cane, which involves the application of a fully organic production system. This means no use is made of fertilizers, herbicides, pesticides, and fungicides. Also full mechanical harvesting is applied without cane burning. In addition it means full compliance with all social, technical, environmental legislation as well as realization of a reforestation programme. Organic sugarcane production presently accounted for $1 \%$ of the total sugarcane area harvested in SP in 2002 [116]. Here we use data about the relative increase in production costs similar to the São Fransisco mill in SP.

3. The production of ethanol taking into account different socio-economic criteria: employment (compensation of the negative employment effect of a ban on cane burning), child labour (ban on child labour), wages and income distribution (an increase of the wage of cane cutters by $50 \%$ is assumed).
4. The production of ethanol, taking into account both environmental criteria (following case 2) and socioeconomic criteria (following case 3).

Results are shown in Fig. 8. Detailed calculations and input data are shown in Appendices $C$ and $D$. The ethanol production costs increase from 0.27 to $0.32 \epsilon_{2005} \mathrm{l}^{-1}$ in case 1 , $0.31 €_{2005} 1^{-1}$ in case $2,,^{23} 0.33 €_{2005} l^{-1}$ in case 3 , and $0.37 €_{2005} l^{-1}$ in case 4 . It should be noted that an organic agriculture production system (case 3 ) is more expensive per hectare than a best management production system (case 2), but the additional costs are compensated by higher yields.

For some areas of concern (genetically modified organisms, social responsibility and benefits, competition with food production, working conditions and worker rights, employment) no costs have been calculated due to a lack of data. The costs of compliance with environmental criteria have been calculated using aggregated data; no results are available for specific issues, with the exception of cane burning, wastewater treatment, and soil erosion.

Since there is no consensus about the definition of sustainability, stricter criteria may be required than assumed in our calculations, which would increase the costs further.

${ }^{23}$ Data about the production costs of organic cane in Argentina indicate that the higher labour costs are compensated by savings on agro-chemicals, so production costs were similar to conventional cane production, but the yields were $25 \%$ lower [117]. This would increase the costs of ethanol by $20 \%$, assuming that sugarcane accounts for $60 \%$ of the total ethanol costs in case of conventional cane production and assuming that the costs of cane decrease linearly with the cane yield. The Fairtrade standards for socially and environmentally responsible production and trade of sugar include a minimum price for organic sugar which is $18-25 \%$ higher than the minimum price for conventional sugar, depending on the type of sugar [108]. If we assume a sugarcane price increase of $25 \%$, and using the same assumptions as above, than the costs of ethanol increase by $15 \%$. 
Table 17 - The evaluation of four aspects based on which conclusions are drawn to what extent an area of concern is a bottleneck for sustainable and certified ethanol production in SP

$\begin{array}{ccccc}\text { Aspect } & \begin{array}{c}(1) \\ \text { Importance } \\ \text { of the area } \\ \text { of concern }\end{array} & \begin{array}{c}\text { (2) } \\ \text { Availability } \\ \text { of indicators } \\ \text { and criteria }\end{array} & \begin{array}{c}\text { (3) Necessity } \\ \text { of } \\ \text { improvement } \\ \text { strategies }\end{array} & \begin{array}{c}\text { (4) Impact of } \\ \text { improvement } \\ \text { strategies on the costs } \\ \text { and potential of } \\ \text { ethanol production }\end{array}\end{array}$

Ecological areas of concern

1. Water use

2. Water pollution

3. Biodiversity (present/future) ${ }^{b}$

4. Soil erosion

5. Fertilizer use

6. Genetically modified

organisms (future)

7. Sugarcane burning

8. Greenhouse gas emission and

energy balance ${ }^{\mathrm{b}}$

Socio-economical areas of concern

9. Competition with food

production $^{\mathrm{b}}$

10. Employment ${ }^{\mathrm{b}}$

11. Income distribution

12. Land tenure

13. Wages

14. Working conditions and

worker rights

15. Child labour

16. Social responsibility and benefits

17. Competitiveness/economic

implications

$\begin{array}{cc}2 & 1 \\ 3 & 1 \\ 1 / 3 & 3 \\ 2 & 2 \\ 2 & 1 \\ 3 & 3 \\ 2 & 1 \\ 3 & 2\end{array}$

2
2
$1 / 3$
2
2
1
1
1

$\begin{array}{cc}1^{\mathrm{a}} & 1 \\ 1^{\mathrm{a}} & 2 \\ 1 / 3 & 1 / 3 \\ 1 & 2 \\ 1^{\mathrm{a}} & 1 \\ 3 & 3 \\ & \\ 1 & 1 \\ 1 & 2\end{array}$

1 = minor bottleneck, 2 = medium bottleneck, 3 = major bottleneck. See text for further explanations.

${ }^{a}$ No data about costs are available for this specific area of concern, but based on the limited additional costs of green and organic cane that include protective measures, we assume that the additional costs are limited.

${ }^{\mathrm{b}}$ Including indirect and induced impacts.

c Based on conventional cane production, thus excluding additional costs resulting from compliance with sustainability criteria.

For example, the net minimum wage necessary for a family of four is calculated at 4.6 times the minimum wage [92]. If we use the factor 4.6 as a criterion for an acceptable wage level of cane cutters, than the costs of ethanol would increase by $41 \%$.

In contrast, cost reductions as a result of technological progress can also be expected: assuming a doubling of the cumulative ethanol production by 2015 and assuming an ethanol experience curve with a progress ratio of 0.8 [114] that is valid in 2015 too than the ethanol production costs will decrease by some $20 \%$. An experience curve depicts the correlation between the cumulative production of ethanol and the production costs per litre; a progress ratio of 0.8 means that for each doubling of cumulative production the costs decrease by $20 \%$. Although no hard data are available, we estimate that the application of genetically modified organisms could reduce the ethanol production costs further, e.g. by growing pest- and disease resistant cane varieties, or by using genetically modified micro-organisms that convert cellulose material (bagasse and barbojo) into fermentable sugars. These gains may be substantial, which also means that the costs of a ban on GM cane (i.e., the benefits of GMSC that are not received) may be substantial. In our calculations the projected costs also exclude revenues from electricity or ethanol production from bagasse and barbojo. Revenues from electricity are expected to generate an income equivalent of $30 \%$ of the production costs of ethanol (assuming the use of all bagasse and $50 \%$ of the trash) [8]. Economically feasible collection and transportation methods for cellulose material are expected to come available on a short term to make this possible. Carbon credits could add another $7.5 \%$, assuming a price of $\mathrm{CO}_{2}$ of $4 \epsilon_{2005} \mathrm{t}^{-1}$; [118]. For comparison: the spot market price of $\mathrm{CO}_{2}$ in 2006 ranged from 4 to $30 €_{2006} \mathrm{t}^{-1} \mathrm{CO}_{2}$ [119]. We conclude that the increase in production costs due to compliance with sustainability criteria is moderate (37\%), at least for the criteria for which costs data are included and assumptions made in this report. However, other criteria could increase these costs substantially.

\section{Conclusions and discussion}

In this article we have analysed which issues are a potential bottleneck for a sustainable production of ethanol from sugarcane from São Paulo (Brazil). Seventeen areas of concern 
Table A1 - Comparison of the greenhouse gas emissions and energy balance of ethanol production in Brazil as presented by Macedo et al. [59] $]^{\mathrm{a}}$ and Oliveira et al. [61]

\begin{tabular}{|c|c|c|c|c|c|c|c|c|c|c|c|c|c|c|c|c|}
\hline & \multirow[t]{3}{*}{ Item } & \multicolumn{6}{|c|}{ Macedo et al. [59] } & & \multirow[t]{3}{*}{ Item } & \multicolumn{6}{|c|}{ Oliveira et al. [61] } & \multirow{3}{*}{$\begin{array}{l}\text { Note } \\
\text { a }\end{array}$} \\
\hline & & \multicolumn{3}{|c|}{ Energy balance } & \multicolumn{3}{|c|}{ GHG emissions } & & & \multicolumn{3}{|c|}{ Energy balance } & \multicolumn{3}{|c|}{ GHG emissions } & \\
\hline & & $\begin{array}{l}\text { Average } \\
\text { case }\end{array}$ & $\begin{array}{l}\text { Best } \\
\text { case }\end{array}$ & Unit & $\begin{array}{l}\text { Average } \\
\text { case }\end{array}$ & $\begin{array}{l}\text { Best } \\
\text { case }\end{array}$ & Unit & & & $\begin{array}{l}\text { Worst } \\
\text { case }\end{array}$ & $\begin{array}{l}\text { Best } \\
\text { case }\end{array}$ & Unit & $\begin{array}{l}\text { Worst } \\
\text { case }\end{array}$ & $\begin{array}{l}\text { Best } \\
\text { case }\end{array}$ & Unit & \\
\hline 1 & $\begin{array}{l}\text { Cane production } \\
\text { Agric. operations, mixed } \\
\text { harvesting }\end{array}$ & 2.6 & 2.6 & GJ ha ${ }^{-1}$ & 193 & 193 & $\mathrm{kgha}^{-1}$ & 1 & $\begin{array}{l}\text { Cane production } \\
\text { Diesel fuel, various } \\
\text { operations }\end{array}$ & 23.0 & 23.0 & $\mathrm{GJ} \mathrm{ha}^{-1}$ & 1848 & 1848 & $\mathrm{kgha}^{-1}$ & $b, c$ \\
\hline 2 & $\begin{array}{l}\text { Agric. operations, manual } \\
\text { harvesting. }\end{array}$ & 1.8 & 1.8 & $\mathrm{GJ} \mathrm{ha}^{-1}$ & 135 & 135 & $\mathrm{kgha}^{-1}$ & 2 & & & & & & & & c \\
\hline 3 & $\begin{array}{l}\text { Agric. operations, } \\
\text { mechanical harvesting }\end{array}$ & 4.1 & 4.1 & GJ ha ${ }^{-1}$ & 301 & 301 & $\mathrm{kgha}^{-1}$ & 3 & & & & & & & & c \\
\hline 4 & Transportation & 3.0 & 2.5 & GJ ha $^{-1}$ & 219 & 186 & $\mathrm{kgha}^{-1}$ & 4 & & & & & & & & \\
\hline 5 & Fertil., lime, agrochem. & 5.9 & 5.7 & $\mathrm{GJ} \mathrm{ha}^{-1}$ & 488 & 470 & $\mathrm{kgha}^{-1}$ & 5 & Fertil., lime, agrochem. & 6.9 & 6.8 & $\mathrm{GJ} \mathrm{ha}^{-1}$ & 434 & 421 & $\mathrm{kgha}^{-1}$ & \\
\hline 6 & Seed & 0.4 & 0.4 & GJ ha $^{-1}$ & Incl. ir & em 5 & & 6 & Seed & 3.4 & 3.4 & $\mathrm{GJ} \mathrm{ha}^{-1}$ & & & & $\mathrm{~d}, \mathrm{f}$ \\
\hline 7 & Equipment & 2.0 & 2.0 & $\mathrm{GJ} \mathrm{ha}^{-1}$ & 158 & 158 & $\mathrm{kgha}^{-1}$ & 7 & & & & & & & & e, \\
\hline 8 & & & & & & & & 8 & Labour & 2.9 & 2.9 & $\mathrm{GJ} \mathrm{ha}^{-1}$ & & & & $e, f$ \\
\hline 9 & $\mathrm{~N}_{2} \mathrm{O}$ from soil & $\mathrm{N} / \mathrm{a}$ & $\mathrm{N} / \mathrm{a}$ & - & 432 & 432 & $\mathrm{kgha}^{-1}$ & 9 & $\mathrm{~N}_{2} \mathrm{O}$; not specified & N/a & $\mathrm{N} / \mathrm{a}$ & - & 465 & 465 & $\mathrm{kgha}^{-1}$ & \\
\hline 10 & $\mathrm{~N}_{2} \mathrm{O}$ from cane burning & N/a & $\mathrm{N} / \mathrm{a}$ & - & 165 & 165 & $\mathrm{kgha}^{-1}$ & 10 & & & & & & & & \\
\hline 11 & $\mathrm{CH}_{4}$, cane burning & N/a & $\mathrm{N} / \mathrm{a}$ & - & 453 & 453 & $\mathrm{kgha}^{-1}$ & 11 & $\mathrm{CH}_{4}$, not specified & N/a & N/a & - & 161 & 161 & $\mathrm{kgha}^{-1}$ & \\
\hline 12 & Total $=1+4+5+6+7+9+10+11$ & 13.9 & 13.2 & $\mathrm{GJ} \mathrm{ha}^{-1}$ & 2108 & 2057 & $\mathrm{kgha}^{-1}$ & 12 & Total $=1+5+6+8+9+11$ & 36.1 & 36.0 & $\mathrm{GJ} \mathrm{ha}^{-1}$ & 2908 & 2895 & $\mathrm{kgha}^{-1}$ & f \\
\hline 13 & Sugarcane yield & 69 & 69 & tha $^{-1}$ & 69 & 69 & tha $^{-1}$ & 13 & Sugarcane yield & 68 & 80 & tha $^{-1}$ & 68 & 80 & tha $^{-1}$ & $\mathrm{~g}$ \\
\hline 14 & $\begin{array}{l}\text { Ethanol production } \\
\text { Conversion cane to ethanol } \\
\text { excl. the use of energy from } \\
\text { bagasse and excl. the } \\
\text { ethanol yield }\end{array}$ & 3.4 & 2.7 & $\mathrm{GJ} \mathrm{ha}^{-1}$ & 261 & 210 & $\mathrm{kgha}^{-1}$ & 14 & $\begin{array}{l}\text { Ethanol production } \\
\text { Conversion cane to } \\
\text { ethanol incl. the use of } \\
\text { energy from bagasse } \\
\text { and excl. the ethanol } \\
\text { yield }\end{array}$ & 3.6 & 3.6 & $\mathrm{GJ} \mathrm{ha}^{-1}$ & 0 & 0 & $\mathrm{kgha}^{-1}$ & f \\
\hline 15 & Surplus bagasse & 11.6 & 21.7 & $\begin{array}{c}\text { GJ } \\
\mathrm{ha}^{-1}\end{array}$ & -859 & -1601 & $\mathrm{kgha}^{-1}$ & 15 & $\begin{array}{l}\text { Surplus electricity from } \\
\text { bagasse }\end{array}$ & 1.5 & 1.5 & $\mathrm{GJ} \mathrm{ha}^{-1}$ & 0 & 0 & $\mathrm{kgha}^{-1}$ & $\mathrm{~h}, \mathrm{f}$ \\
\hline 16 & Ethanol yield & 86 & 92 & $1 t^{-1}$ & 86 & 92 & $1 t^{-1}$ & 16 & Ethanol yield & 80 & 85 & $1 t^{-1}$ & 80 & 85 & $1 t^{-1}$ & $\mathrm{i}$ \\
\hline 17 & Ethanol yield & 132 & 141 & $\mathrm{GJ} \mathrm{H}^{-1}$ & $\mathrm{~N} / \mathrm{a}$ & $\mathrm{N} / \mathrm{a}$ & - & 17 & Ethanol yield & 127 & 159 & GJ ha ${ }^{-1}$ & N/a & $\mathrm{N} / \mathrm{a}$ & - & \\
\hline 18 & Ethanol distribution & & & & & & & 18 & $\begin{array}{l}\text { Ethanol distribution } \\
\text { Ethanol distribution }\end{array}$ & 2.8 & 2.8 & $\mathrm{GJ} \mathrm{ha}^{-1}$ & 227 & 227 & $\mathrm{kgha}^{-1}$ & e \\
\hline
\end{tabular}




\begin{tabular}{|c|c|c|c|c|c|c|c|c|c|c|c|c|c|c|c|c|}
\hline 19 & $\begin{array}{l}\text { Grand total } \\
\text { Total energy } \\
\text { output }=15+17\end{array}$ & 144 & 163 & GJ ha $^{-1}$ & & & & 19 & $\begin{array}{l}\text { Grand total } \\
\text { Total energy } \\
\text { output }=14+15+17\end{array}$ & 132 & 164 & $\mathrm{GJ} \mathrm{ha}^{-1}$ & & & & $\mathrm{~h}$ \\
\hline 20 & Total energy input $=12+14$ & 17 & 16 & GJ ha $^{-1}$ & & & & 20 & $\begin{array}{l}\text { Total energy } \\
\text { input }=12+14+18\end{array}$ & 42.6 & 42.4 & GJ ha ${ }^{-1}$ & & & & $\mathrm{~h}$ \\
\hline 21 & $\begin{array}{l}\text { Energy output:input }=19 / \\
20\end{array}$ & 8.3 & 10.2 & - & & & & 21 & $\begin{array}{l}\text { Energy } \\
\text { output:input }=19 / 20\end{array}$ & 3.1 & 3.9 & - & & & & f \\
\hline 22 & $\begin{array}{l}\text { GHG } \\
\text { emissions }=(12+14+15) / \\
(13 \times 16 \times 0.001)\end{array}$ & & & & 256 & 106 & $\mathrm{~kg} \mathrm{~m}^{-3}$ & 22 & $\begin{array}{l}\text { GHG } \\
\text { emissions }=(12+14+15) / \\
(13 \times 16 \times 0.001)\end{array}$ & & & & 535 & 426 & $\mathrm{~kg} \mathrm{~m}^{-3}$ & \\
\hline
\end{tabular}

$\mathrm{N} / \mathrm{a}=$ not applicable

${ }^{a}$ Macedo and his team carried out several studies about the energy balance and GHG emissions of ethanol from sugarcane. His most recent work is used in this article.

${ }^{b}$ Macedo presents data for manual harvesting, mechanical harvesting, and for the mix of manual and mechanical harvesting presently used in SP. Data for the average mix of manual and mechanical harvesting (65\% and 35\%, respectively) are included in the final results. The data on manual and mechanical harvesting are shown, because they are used elsewhere to calculate the impact of compliance with sustainability criteria on the GHG balance.

${ }^{c}$ Oliveira assumed a value of $23 \mathrm{GJ} \mathrm{ha}^{-1}$ for agricultural operations, which is probably erroneous; Macedo reports a value of $2.6 \mathrm{GJ}^{\mathrm{J}} \mathrm{a}^{-1}$. The $2.6 \mathrm{GJ}$ ha ${ }^{-1}$ for agricultural operations is based on $65 \%$ manual harvesting (for which the primary energy use is zero) and $35 \%$ mechanical harvesting, which is representative for SP.

d The energy use for seed is calculated to be 0.4 and $3.4 \mathrm{GJ} \mathrm{ha}^{-1}$ by Macedo and Oliveira, respectively. A more detailed analysis was not possible due to a lack of data.

e There are several differences in system boundaries: Moreira includes energy use of manual labour and ethanol distribution; both are excluded in Macedo's work. However, Macedo mentions a value of $0.5 \mathrm{GJ} \mathrm{ha}^{-1}$ for manual labour. Further, Macedo includes the energy use and GHG emissions from the production of equipment, which Oliveira excluded.

${ }^{\mathrm{f}}$ There is a difference in the definition of the energy balance, i.e. the ratio of energy output to energy input, see lines 19-21. The main difference is that Macedo excludes the use of energy from bagasse combustion and only considers the use of fossil energy sources. Oliveira includes the use of energy from bagasse for ethanol production in both the energy input and output; the use of fossil energy is zero. We prefer the approach used by Macedo, because the use of bagasse represents an internal flux of energy; we also apply this approach in the calculations presented elsewhere in this article. Further, the $\mathrm{CO}_{2}$ emissions per kg reported here for Oliveira are slightly lower than the values reported in the original article $\left(461\right.$ and $\left.572 \mathrm{~kg} \mathrm{CO}_{2} \mathrm{~m}^{-3}\right)$. The reason for this difference is not known, possibly some emissions were included for labour, ethanol production or co-generation of electricity that have not been specified in the article.

$\mathrm{g}$ The value of $80 \mathrm{tha}^{-1} \mathrm{yr}^{-1}$ is derived from the literature [120] and represents the average yield per harvest in SP (best case), excluding the first harvest. Yields are lower in case the first harvest is also included: Macedo reports an average yield of $82 \mathrm{tha}^{-1} \mathrm{yr}^{-1}$ in SP, excluding the first harvest, or $69 \mathrm{tha}^{-1} \mathrm{yr}^{-1}$ in case also the first harvest is included).

${ }^{\mathrm{h}}$ There is a difference in the definition of surplus energy from bagasse: Oliveira reports a surplus of $1.5 \mathrm{GJ}$ electricity ha ${ }^{-1}$, Macedo reports a value of $11.6-21.7 \mathrm{GJ}$ of surplus bagasse ha ${ }^{-1}$. Further, Macedo calculates avoided emissions assuming that the surplus bagasse replaces fuel oil in other industries (orange juice, pulp and paper).

${ }^{\mathrm{i}}$ Macedo assumes an ethanol yield of $861 \mathrm{t}^{-1}$ (average case in SP) and $921 \mathrm{t}^{-1}$ (best case in SP) compared to $851 \mathrm{t}^{-1}$ (best case) and $801 \mathrm{t}^{-1}$ (worst case; [6]) included in Oliveira's study. There has been a continuous increase in the ethanol yield, which is an explanation for the difference: the data in Macedo are from 2003 and data in Oliveira are from 1999 . We assume the following yields: $861 \mathrm{t}^{-1}$ (average case), $921 \mathrm{t}^{-1}$ (best case), and $801 \mathrm{t}^{-1}$ (worst case). For the future, we assume a yield of $1141 \mathrm{t}^{-1}$ in 2030 [63]. 
Table A2 - The input data and assumptions used in the calculations of the greenhouse gas emissions and energy balance of ethanol production in São Paulo

\begin{tabular}{|c|c|c|c|c|c|c|c|c|c|c|c|c|c|c|}
\hline & \multirow[b]{3}{*}{ Worst (W), average (A), best (B), N/a } & \multicolumn{12}{|c|}{ Energy balance ethanol production } & \multirow[t]{3}{*}{ Unit } \\
\hline & & \multicolumn{6}{|c|}{ Present } & \multicolumn{6}{|c|}{ Future } & \\
\hline & & $\mathrm{W}$ & A & B & $\mathrm{W}$ & A & B & $\mathrm{N} / \mathrm{a}$ & $\mathrm{N} / \mathrm{a}$ & $\mathrm{N} / \mathrm{a}$ & $\mathrm{N} / \mathrm{a}$ & $\mathrm{N} / \mathrm{a}$ & $\mathrm{N} / \mathrm{a}$ & \\
\hline & Sugarcane production & & & & & & & & & & & & & \\
\hline 0 & Cane burning (\% of area) & 75 & 75 & 75 & 0 & 0 & 0 & 75 & 75 & 75 & 0 & 0 & 0 & $\%$ \\
\hline 1 & Agric. operations ${ }^{\mathrm{a}}$ & 2.1 & 2.7 & 3.2 & 3.3 & 4.1 & 4.9 & 3.9 & 3.9 & 3.9 & 5.9 & 5.9 & 5.9 & $\mathrm{GJ} \mathrm{ha}^{-1}$ \\
\hline 2 & Agric. operations, manual harvesting ${ }^{a, b}$ & 1.5 & 1.9 & 2.3 & $\mathrm{~N} / \mathrm{a}$ & $\mathrm{N} / \mathrm{a}$ & $\mathrm{N} / \mathrm{a}$ & 2.8 & 2.8 & 2.8 & $\mathrm{~N} / \mathrm{a}$ & $\mathrm{N} / \mathrm{a}$ & $\mathrm{N} / \mathrm{a}$ & GJ ha ${ }^{-1}$ \\
\hline 3 & Agric. operations, mechanical harvesting ${ }^{\mathrm{a}}$ & 3.3 & 4.1 & 4.9 & 3.3 & 4.1 & 4.9 & 5.9 & 5.9 & 5.9 & 5.9 & 5.9 & 5.9 & $\mathrm{GJ} \mathrm{ha}^{-1}$ \\
\hline 4 & Transportation $^{\mathrm{a}}$ & 2.7 & 3.0 & 3.0 & 2.7 & 3.0 & 3.0 & 3.7 & 3.7 & 3.7 & 3.7 & 3.7 & 3.7 & $\mathrm{GJ} \mathrm{ha}^{-1}$ \\
\hline 5 & Fertil., lime, agrochem ${ }^{c}$ & 6.1 & 5.9 & 5.7 & 6.1 & 5.9 & 5.7 & 5.7 & 5.7 & 5.7 & 5.7 & 5.7 & 5.7 & $\mathrm{GJ} \mathrm{ha}^{-1}$ \\
\hline 6 & Seed & 0.4 & 0.4 & 0.4 & 0.4 & 0.4 & 0.4 & 0.4 & 0.4 & 0.4 & 0.4 & 0.4 & 0.4 & $\mathrm{GJ} \mathrm{ha}^{-1}$ \\
\hline 7 & Equipment ${ }^{\mathrm{c}}$ & 2.0 & 2.0 & 2.0 & 2.0 & 2.0 & 2.0 & 2.0 & 2.0 & 2.0 & 2.0 & 2.0 & 2.0 & $\mathrm{GJ} \mathrm{ha}^{-1}$ \\
\hline 8 & Labour & \multicolumn{13}{|c|}{ Included in agricultural operations } \\
\hline 9 & $\mathrm{~N}_{2} \mathrm{O}$ from soil ${ }^{\mathrm{c}}$ & $\mathrm{N} / \mathrm{a}$ & $\mathrm{N} / \mathrm{a}$ & $\mathrm{N} / \mathrm{a}$ & $\mathrm{N} / \mathrm{a}$ & $\mathrm{N} / \mathrm{a}$ & $\mathrm{N} / \mathrm{a}$ & $\mathrm{N} / \mathrm{a}$ & $\mathrm{N} / \mathrm{a}$ & $\mathrm{N} / \mathrm{a}$ & $\mathrm{N} / \mathrm{a}$ & $\mathrm{N} / \mathrm{a}$ & $\mathrm{N} / \mathrm{a}$ & N/a \\
\hline 10 & $\mathrm{~N}_{2} \mathrm{O}$ from cane burning ${ }^{\mathrm{d}}$ & $\mathrm{N} / \mathrm{a}$ & $\mathrm{N} / \mathrm{a}$ & $\mathrm{N} / \mathrm{a}$ & $\mathrm{N} / \mathrm{a}$ & N/a & N/a & $\mathrm{N} / \mathrm{a}$ & $\mathrm{N} / \mathrm{a}$ & $\mathrm{N} / \mathrm{a}$ & $\mathrm{N} / \mathrm{a}$ & N/a & $\mathrm{N} / \mathrm{a}$ & N/a \\
\hline 11 & $\mathrm{CH}_{4}$, cane burning ${ }^{\mathrm{d}}$ & $\mathrm{N} / \mathrm{a}$ & $\mathrm{N} / \mathrm{a}$ & $\mathrm{N} / \mathrm{a}$ & $\mathrm{N} / \mathrm{a}$ & $\mathrm{N} / \mathrm{a}$ & $\mathrm{N} / \mathrm{a}$ & $\mathrm{N} / \mathrm{a}$ & $\mathrm{N} / \mathrm{a}$ & $\mathrm{N} / \mathrm{a}$ & $\mathrm{N} / \mathrm{a}$ & $\mathrm{N} / \mathrm{a}$ & $\mathrm{N} / \mathrm{a}$ & $\mathrm{N} / \mathrm{a}$ \\
\hline 12 & Total $=1+4+5+6+7+8+9+10+11$ & 13.3 & 13.9 & 14.3 & 14.5 & 15.3 & 16.0 & 15.6 & 15.6 & 15.6 & 17.7 & 17.7 & 17.7 & $\mathrm{GJ} \mathrm{ha}^{-1}$ \\
\hline \multirow[t]{2}{*}{13} & Sugarcane yielde & 55 & 69 & 82 & 55 & 69 & 82 & 100 & 100 & 100 & 100 & 100 & 100 & tha $^{-1}$ \\
\hline & Ethanol production & & & & & & & & & & & & & \\
\hline 14 & Cane to $\mathrm{EtOH}^{\mathrm{f}, \mathrm{g}}$ & 4.5 & 3.4 & 2.3 & 4.5 & 3.4 & 2.3 & 2.8 & 2.8 & 2.8 & 2.8 & 2.8 & 2.8 & $\mathrm{GJ} \mathrm{ha}^{-1}$ \\
\hline 15 & Cogeneration technology (see Table 9) & $\mathrm{N} / \mathrm{a}$ & $\mathrm{N} / \mathrm{a}$ & $\mathrm{N} / \mathrm{a}$ & $\mathrm{N} / \mathrm{a}$ & $\mathrm{N} / \mathrm{a}$ & $\mathrm{N} / \mathrm{a}$ & 2 & 3 & 4 & 2 & 3 & 4 & - \\
\hline $16 a$ & Surplus electr. in prim. energy, natural gas fired capacity as reference ${ }^{h}$ & 0.0 & 2.9 & 5.9 & 0.0 & 2.9 & 5.9 & 7.2 & 56 & 169 & 7.2 & 79 & 216 & $\mathrm{GJha}^{-1}$ \\
\hline $16 b$ & Surplus electr. in prim. energy, recently average capacity as reference ${ }^{\mathrm{h}}$ & 0.0 & 0.5 & 1.0 & 0.0 & 0.5 & 1.0 & 1.2 & 9.3 & 28 & 1.2 & 13 & 36 & GJ ha ${ }^{-1}$ \\
\hline 17 & Ethanol yield & 80 & 86 & 92 & 80 & 86 & 92 & 114 & 114 & 114 & 114 & 114 & 114 & $1 t^{-1}$ \\
\hline \multirow[t]{2}{*}{18} & Ethanol yield & 98 & 132 & 169 & 98 & 132 & 169 & 255 & 255 & 255 & 255 & 255 & 255 & $\mathrm{GJ} \mathrm{ha}^{-1}$ \\
\hline & $\begin{array}{l}\text { Grand total } \\
\text { Energy output:input ratio }=(16+18) /(12+14)\end{array}$ & & & & & & & & & & & & & \\
\hline $19 a$ & NG-fired capacity as reference & 5.5 & 7.8 & 10.6 & 5.2 & 7.2 & 9.6 & 14.3 & 16.9 & 23.1 & 12.8 & 16.3 & 23.0 & - \\
\hline $19 b$ & $\begin{array}{l}\text { Recently average installed capacity as reference } \\
\text { GHG emissions }=(12+14+16) /(13 \times 17 \times 0.001)\end{array}$ & 5.5 & 7.7 & 10.3 & 5.2 & 7.1 & 9.3 & 13.9 & 14.4 & 15.4 & 12.5 & 13.1 & 14.2 & - \\
\hline $20 a$ & Natural gas-fired capacity as reference & $\mathrm{N} / \mathrm{a}$ & $\mathrm{N} / \mathrm{a}$ & $\mathrm{N} / \mathrm{a}$ & $\mathrm{N} / \mathrm{a}$ & $\mathrm{N} / \mathrm{a}$ & $\mathrm{N} / \mathrm{a}$ & $\mathrm{N} / \mathrm{a}$ & $\mathrm{N} / \mathrm{a}$ & $\mathrm{N} / \mathrm{a}$ & $\mathrm{N} / \mathrm{a}$ & $\mathrm{N} / \mathrm{a}$ & $\mathrm{N} / \mathrm{a}$ & $\mathrm{N} / \mathrm{a}$ \\
\hline $20 b$ & Recently average installed capacity as reference & $\mathrm{N} / \mathrm{a}$ & $\mathrm{N} / \mathrm{a}$ & $\mathrm{N} / \mathrm{a}$ & $\mathrm{N} / \mathrm{a}$ & $\mathrm{N} / \mathrm{a}$ & $\mathrm{N} / \mathrm{a}$ & $\mathrm{N} / \mathrm{a}$ & $\mathrm{N} / \mathrm{a}$ & $\mathrm{N} / \mathrm{a}$ & $\mathrm{N} / \mathrm{a}$ & $\mathrm{N} / \mathrm{a}$ & $\mathrm{N} / \mathrm{a}$ & $\mathrm{N} / \mathrm{a}$ \\
\hline
\end{tabular}




\begin{tabular}{|c|c|c|c|c|c|c|c|c|c|c|c|c|c|c|}
\hline & \multirow[b]{3}{*}{ Worst (W), average (A), best (B), N/a } & \multicolumn{12}{|c|}{ Greenhouse gas emissions ethanol production } & \multirow[t]{3}{*}{ Unit } \\
\hline & & \multicolumn{6}{|c|}{ Present } & \multicolumn{6}{|c|}{ Future } & \\
\hline & & $\mathrm{W}$ & A & B & $\mathrm{W}$ & A & B & $\mathrm{N} / \mathrm{a}$ & $\mathrm{N} / \mathrm{a}$ & $\mathrm{N} / \mathrm{a}$ & $\mathrm{N} / \mathrm{a}$ & N/a & $\mathrm{N} / \mathrm{a}$ & \\
\hline & Sugarcane production & & & & & & & & & & & & & \\
\hline 0 & Cane burning (\% of area) & 75 & 75 & 75 & 0 & 0 & 0 & 75 & 75 & 75 & 0 & 0 & 0 & $\%$ \\
\hline 1 & Agric. operations ${ }^{a}$ & 168 & 209 & 251 & 241 & 301 & 361 & 305 & 305 & 305 & 438 & 438 & 438 & $\mathrm{kgha}^{-1}$ \\
\hline 2 & Agric. operations, manual harvesting ${ }^{\mathrm{a}, \mathrm{b}}$ & 128 & 160 & 192 & $\mathrm{~N} / \mathrm{a}$ & $\mathrm{N} / \mathrm{a}$ & $\mathrm{N} / \mathrm{a}$ & 233 & 233 & 233 & N/a & N/a & $\mathrm{N} / \mathrm{a}$ & $\mathrm{kgha}^{-1}$ \\
\hline 3 & Agric. operations, mechanical harvesting ${ }^{a}$ & 241 & 301 & 361 & 241 & 301 & 361 & 438 & 438 & 438 & 470 & 470 & 470 & $\mathrm{kgha}^{-1}$ \\
\hline 4 & Transportation $^{\mathrm{a}}$ & 201 & 219 & 224 & 201 & 219 & 224 & 271 & 271 & 271 & 219 & 219 & 219 & $\mathrm{kgha}^{-1}$ \\
\hline 5 & Fertil., lime, agrochem. ${ }^{c}$ & 486 & 488 & 480 & 486 & 488 & 480 & 486 & 486 & 486 & 488 & 488 & 488 & $\mathrm{kgha}^{-1}$ \\
\hline 6 & Seed & \multicolumn{12}{|c|}{ Included in fertilizers lime, agrochemicals } & \\
\hline 7 & Equipment $^{\mathrm{c}}$ & 158 & 158 & 158 & 158 & 158 & 158 & 158 & 158 & 158 & 158 & 158 & 158 & $\mathrm{kgha}^{-1}$ \\
\hline 8 & Labour & \multicolumn{12}{|c|}{ Included in agricultural operations } & \\
\hline 9 & $\mathrm{~N}_{2} \mathrm{O}$ from soil ${ }^{\mathrm{c}}$ & 432 & 432 & 432 & 432 & 432 & 432 & 432 & 432 & 432 & 432 & 432 & 432 & $\mathrm{kgha}^{-1}$ \\
\hline 10 & $\mathrm{~N}_{2} \mathrm{O}$ from cane burning ${ }^{\mathrm{d}}$ & 132 & 165 & 198 & $\mathrm{~N} / \mathrm{a}$ & $\mathrm{N} / \mathrm{a}$ & N/a & 132 & 132 & 132 & N/a & $\mathrm{N} / \mathrm{a}$ & $\mathrm{N} / \mathrm{a}$ & $\mathrm{kgha}^{-1}$ \\
\hline 11 & $\mathrm{CH}_{4}$, cane burning ${ }^{\mathrm{d}}$ & 362 & 453 & 544 & $\mathrm{~N} / \mathrm{a}$ & $\mathrm{N} / \mathrm{a}$ & N/a & 362 & 362 & 362 & N/a & $\mathrm{N} / \mathrm{a}$ & N/a & $\mathrm{kgha}^{-1}$ \\
\hline 12 & Total $=1+4+5+6+7+8+9+10+11$ & 1940 & 2124 & 2286 & 1519 & 1598 & 1655 & 2147 & 2147 & 2147 & 2205 & 2205 & 2205 & $\mathrm{kgha}^{-1}$ \\
\hline \multirow[t]{2}{*}{13} & Sugarcane yield & 55 & 69 & 82 & 55 & 69 & 82 & 100 & 100 & 100 & 100 & 100 & 100 & tha ${ }^{-1}$ \\
\hline & Ethanol production & & & & & & & & & & & & & \\
\hline 14 & Cane to $\mathrm{EtOH}^{\mathrm{f}, \mathrm{g}}$ & 250 & 261 & 252 & 250 & 261 & 252 & 306 & 306 & 306 & 306 & 306 & 306 & $\mathrm{kgha}^{-1}$ \\
\hline 15 & Cogeneration technology (see Table 9) & $\mathrm{N} / \mathrm{a}$ & $\mathrm{N} / \mathrm{a}$ & $\mathrm{N} / \mathrm{a}$ & $\mathrm{N} / \mathrm{a}$ & $\mathrm{N} / \mathrm{a}$ & N/a & 2 & 3 & 4 & 2 & 3 & 4 & - \\
\hline $16 a$ & $\begin{array}{l}\text { Surplus electr. in prim. energy, natural gas fired capacity as } \\
\text { reference }^{\text {h }}\end{array}$ & 0 & -164 & -333 & 0 & -164 & -333 & -404 & -3131 & -9495 & -404 & -4444 & -12121 & $\mathrm{kgha}^{-1}$ \\
\hline $16 \mathrm{~b}$ & $\begin{array}{l}\text { Surplus electr. in prim. energy, recently average capacity as } \\
\text { reference }^{\text {h }}\end{array}$ & 0 & -44 & -90 & 0 & -44 & -90 & -109 & -845 & -2562 & -109 & -1199 & -3270 & $\mathrm{kgha}^{-1}$ \\
\hline 17 & Ethanol yield & 80 & 86 & 92 & 80 & 86 & 92 & 114 & 114 & 114 & 114 & 114 & 114 & $1 t^{-1}$ \\
\hline \multirow[t]{2}{*}{18} & Ethanol yield & 98 & 132 & 169 & 98 & 132 & 169 & 255 & 255 & 255 & 255 & 255 & 255 & - \\
\hline & $\begin{array}{l}\text { Grand total } \\
\text { Energy output:input ratio }=(16+18) /(12+14)\end{array}$ & & & & & & & & & & & & & \\
\hline $19 a$ & NG-fired capacity as reference & $\mathrm{N} / \mathrm{a}$ & N/a & N/a & $\mathrm{N} / \mathrm{a}$ & N/a & N/a & $\mathrm{N} / \mathrm{a}$ & $\mathrm{N} / \mathrm{a}$ & N/a & N/a & $\mathrm{N} / \mathrm{a}$ & $\mathrm{N} / \mathrm{a}$ & N/a \\
\hline
\end{tabular}


Greenhouse gas emissions ethanol production

\begin{tabular}{|c|c|c|c|c|c|c|c|c|c|c|c|c|c|c|}
\hline & \multirow[b]{3}{*}{ Worst (W), average (A), best (B), N/a } & \multicolumn{12}{|c|}{ Greenhouse gas emissions ethanol production } & \multirow[t]{3}{*}{ Unit } \\
\hline & & \multicolumn{6}{|c|}{ Present } & \multicolumn{6}{|c|}{ Future } & \\
\hline & & W & A & B & W & A & B & $\mathrm{N} / \mathrm{a}$ & $\mathrm{N} / \mathrm{a}$ & $\mathrm{N} / \mathrm{a}$ & $\mathrm{N} / \mathrm{a}$ & $\mathrm{N} / \mathrm{a}$ & $\mathrm{N} / \mathrm{a}$ & \\
\hline $19 b$ & $\begin{array}{l}\text { Recently average installed capacity as reference } \\
\text { GHG emissions }=(12+14+16) /(13 \times 17 \times 0.001)\end{array}$ & $\mathrm{N} / \mathrm{a}$ & N/a & N/a & $\mathrm{N} / \mathrm{a}$ & N/a & $\mathrm{N} / \mathrm{a}$ & $\mathrm{N} / \mathrm{a}$ & $\mathrm{N} / \mathrm{a}$ & $\mathrm{N} / \mathrm{a}$ & $\mathrm{N} / \mathrm{a}$ & N/a & $\mathrm{N} / \mathrm{a}$ & N/a \\
\hline $20 \mathrm{a}$ & Natural gas-fired capacity as reference & 498 & 376 & 282 & 402 & 287 & 199 & 180 & -59 & -618 & 185 & -170 & -843 & $\mathrm{~kg} \mathrm{~m}^{-3}$ \\
\hline $20 b$ & Recently average installed capacity as reference & 498 & 396 & 321 & 402 & 307 & 238 & 206 & 141 & -10 & 211 & 115 & -67 & $\mathrm{~kg} \mathrm{~m}^{-3}$ \\
\hline
\end{tabular}

N/a = not applicable.Sources: [59,63-65] plus own assumptions.

${ }^{a}$ Data for the worst-case situation are calculated by assuming that the (relative) difference between average case and best case is the same as the difference between average case and worst case (per hectare). This calculation excludes the impact of sugarcane yields. We also correct for differences in sugarcane yield, assuming that the energy use and emissions are constant per tonne sugarcane. The final results include the data on energy use and emissions from agricultural operations (line 1). The other data presented for agricultural operations, manual harvesting, and for agricultural operations and manual harvesting are shown to indicate the impact of the choice of the harvesting system.

$\mathrm{b}$ The energy consumption and greenhouse gas emissions of manual labour are added, based on the following assumptions: $17 \mathrm{EJ}$ fossil energy was used for food production in 2001 (sum of agriculture, food and tobacco industry, and $1.2 \%$ of the energy use in industry is used for fertilizer production) [121,122]. The corresponding GHG emissions from agriculture in 2001 were $5.6 \mathrm{GtCO}{ }_{2}$ eq., including $\mathrm{CO}_{2}, \mathrm{CH}_{4}, \mathrm{~N}_{2} \mathrm{O}, \mathrm{HFC}, \mathrm{PFC}, \mathrm{SFC}$ and excluding emissions from land use changes [123]. The total food intake in 2001 was $6.0 \mathrm{EJ}$ [40]; $400 \mathrm{kcal} \mathrm{t}{ }^{-1}$ sugarcane is required for manual harvesting [59].

including $\mathrm{CO}_{2}, \mathrm{CH}_{4}, \mathrm{~N}_{2} \mathrm{O}$, $\mathrm{HFC}$, $\mathrm{PFC}$.

d Assumed constant per tonne sugarcane; data are corrected for differences in sugarcane yield.

${ }^{\mathrm{e}}$ We assume a yield of $69 \mathrm{tha}^{-1} \mathrm{yr}^{-1}$ (average case, present yield in SP) $\pm 20 \%$ for the best case/worst case. For the future we assume a yield of $100 \mathrm{tha} \mathrm{yr}^{-1} \mathrm{yr}^{-1}$, which seems conservative considering the $140 \mathrm{tha}^{-1} \mathrm{yr}^{-1}$ for 2030 assumed by Moreira [63]; $100 \mathrm{tha}^{-1} \mathrm{yr}^{-1}$ is in line with the average cane yield increase during the previous two decades of $0.7 \% \mathrm{yr}^{-1}$, assuming a 30 -year time period. At this moment yields of 100-110 $\mathrm{tha}^{-1} \mathrm{yr}^{-1}$ are already achieved in some areas in SP [120].

${ }_{\mathrm{f}}^{\mathrm{f}}$ Data for present, worst case are calculated by assuming that the (relative) difference between average case and best case is the same as the difference between average case and worst case. Further, the data are corrected for differences in ethanol yield, whereby we assume that the energy use and emissions are constant per litre ethanol.

${ }^{g}$ Giampietro and Ulgiati [124] estimated that the removal of organic substances from wastewaters via intensive wastewater treatment requires $10.5 \mathrm{GJ} \mathrm{m}^{-3}$ ethanol, which would reduce the energy balance of the present average as calculated by Macedo from 8.3 to 1.8. However, in practice, alternatives are available and therefore intensive wastewater treatment is excluded.

${ }^{\mathrm{h}}$ The number on energy represents avoided primary energy. For the present situation average case we use a figure of $5.9 \mathrm{kWh} \mathrm{e}^{-1}$ cane, which is the average surplus electricity sold to the grid in 2004 in SP [63]. For the present situation best case we assume cogeneration technology 2 and for the worst case we assumed no production of surplus electricity. Other data and assumptions used in the calculations: the average consumption of electricity for the production of cane is $28 \mathrm{kWh}_{\mathrm{e}} \mathrm{t}^{-1}$ cane [64]. The availability of barbojo for electricity generation is corrected for cane burning (barbojo is burnt) and for the use for soil protection and weed control and for losses during collection (50\% of the barbojo is left in the field). The emissions of $\mathrm{CH}_{4}$ from bagasse burning are negligible [59]. The emissions of $\mathrm{N}_{2} \mathrm{O}$ from bagasse burning are also ignored, because the impact is limited: $\mathrm{N}_{2} \mathrm{O}$ emissions decrease the credit of cogeneration by $10 \%$ or less. 


\section{Table A3 - The additional ethanol production costs of compliance with various sustainability criteria ${ }^{\mathrm{a}}$}

\begin{tabular}{|c|c|c|c|c|}
\hline \multicolumn{2}{|c|}{ Area(s) of concern } & Criterion & \multirow{2}{*}{$\begin{array}{c}\begin{array}{c}\text { Costs } \\
\left(€_{2005} l^{-1}\right)\end{array} \\
0.27\end{array}$} & \multirow{2}{*}{$\begin{array}{c}\begin{array}{c}\text { Cost } \\
\text { increase } \\
(\%)\end{array} \\
0\end{array}$} \\
\hline- & $\begin{array}{l}\text { Conventional } \\
\text { production }\end{array}$ & No criterion; conventional sugarcane and ethanol production ${ }^{\mathrm{b}}$ & & \\
\hline 4 & Soil erosion & $\begin{array}{c}\text { Reduction of soil erosion from } 20 \mathrm{tha}^{-1} \mathrm{yr}^{-1} \text { to a level equal to the natural } \\
\text { rate of soil formation }{ }^{\mathrm{c}}\end{array}$ & 0.28 & 3 \\
\hline 7,10 & $\begin{array}{l}\text { Cane burning and } \\
\text { employment }\end{array}$ & Reduction of cane burning to zero ${ }^{\mathrm{d}, \mathrm{e}}$ & 0.29 & 8 \\
\hline 11,13 & $\begin{array}{l}\text { Wages and income } \\
\text { distribution }\end{array}$ & Increase of the wage of cane cutters by $50 \%$ e,f & 0.28 & 4 \\
\hline 15 & Child labour & Reduction of child labour to zero ${ }^{\mathrm{e}, \mathrm{g}}$ & 0.29 & 4 \\
\hline $1-17$ & $\begin{array}{l}\text { Various, mainly } \\
\text { environmental areas of } \\
\text { concern }\end{array}$ & $\begin{array}{l}\text { Green cane. Application of best management practice, including } \\
\text { compliance with all social, technical, environmental legislation }{ }^{\mathrm{h}}\end{array}$ & 0.29 & 9 \\
\hline $1-17$ & $\begin{array}{l}\text { Various, mainly } \\
\text { environmental areas of } \\
\text { concern }\end{array}$ & $\begin{array}{c}\text { Organic cane. Application of a fully organic and certified production } \\
\text { system, including compliance with all social, technical, environmental } \\
\text { legislation }\end{array}$ & 0.29 & 8 \\
\hline 2 & Water pollution & Full wastewater treatment and/or recycling ${ }^{\mathrm{i}}$ & 0.29 & 9 \\
\hline $1-8$ & $\begin{array}{l}\text { Various environmental } \\
\text { areas of concern }\end{array}$ & $\begin{array}{c}\text { Application of technologies that protect the environment during the } \\
\text { processing of cane into ethanol }\end{array}$ & 0.29 & 8 \\
\hline
\end{tabular}

a The costs of the certification procedure are limited to $0.5 \%$ of the total production costs and are therefore ignored, see further Table A4.

${ }^{b}$ The average price of hydrated and anhydrated ethanol in 2005 paid to the producer in Brazil is used as a proxy of the production costs [125]. In reality the production costs are likely lower.

${ }^{c}$ The natural rate of soil formation $2 \mathrm{tha}^{-1} \mathrm{yr}^{-1}$ [48]. We assume a cost of soil erosion prevention of $2.3 \epsilon_{2005} \mathrm{t}^{-1}$ avoided soil loss [data are average for the US, 126], a sugarcane yield of $69 \mathrm{tha}^{-1} \mathrm{yr}^{-1}$ and an ethanol yield of $861 \mathrm{t}^{-1}$, which are the same as used in the GHG emissions and energy balance calculations.

${ }^{d}$ We assume that all manual cane harvesting is replaced by mechanical harvesting. The impact of the reduction in employment can be compensated by unemployment benefits or by increasing the labour intensity of cane production. The additional costs are assumed equal to the present costs of manual harvesting, thereby assuming that the costs of manual harvested cane is the same as mechanically harvested cane (excluding compensation for unemployment). The compensation of unemployment leads to a doubling of the harvesting costs, which is likely an overestimation, because the costs of mechanically harvested cane are lower compared to manually harvested cane [120]. An alternative compensation strategy would be the manual harvesting of green cane, but this would increase the employment in cane harvesting by a factor of five compared to conventional cane production. Other disadvantages of manual green harvesting are the unsafe (vipers) and harmful (cutting leaves silicate crystals). Further, the production costs of manual and mechanical harvesting are assumed equal, except for the costs of compensation of the negative employment effects.

${ }^{e}$ Assuming that $60 \%$ of the ethanol production costs consists of cane production costs $[8,114]$ and assuming that $23 \%$ of the cane production costs are labour costs, $60 \%$ of which is related to unskilled labour used in harvesting [127]. The costs of unskilled labour used in harvesting equals $2.2 €$ cent $^{-1}$ for mechanically and manually harvested cane or $3.4 € c e n t l^{-1}$ for manually harvested cane only. Ripoli and Ripoli [88] report a value of $2.9 €$ cent $^{-1}$ for manual harvested cane (without mechanical help).

$\mathrm{f}$ The labour costs are assumed to increase corresponding to the increase in wages.

${ }^{g}$ Additional costs include two types of financial compensation, which are added to the labour costs. The first type is the compensation of the loss of family income, which is estimated at $74 €_{2005}$ month $^{-1}$ child $^{-1}$ [128] assuming 20 working days per month. The second type is the compensation of the costs of education to ensure that children are able to go to school and are not sent to work elsewhere. For the costs of education the public expenditures per pupil are used as a proxy, which are $50 \epsilon_{2005}$ month $^{-1}$ child $^{-1}$ [129]. The calculations are based on an average family of four, two adults and two children, of which one adult is employed in cane cutting who receives compensation for both children. Further, we include compensation for all $50 \%$ of the employees involved in cane production, which is likely an overestimation, because only a fraction of the children is involved in child labour. We assume an average wage of $262 \epsilon_{2005}$ month $^{-1}$ in the sugarcane sector in SP [8].

$\mathrm{h}$ The increase in production costs is based on the relative increase in production costs of green cane and organic cane, compared to conventional cane production, based on data from the São Fransisco mill in SP, which the largest organic sugar mill in Brazil. Detailed data are shown in Table A4. We assume that cane accounts for $60 \%$ of the ethanol production costs in case of conventional cane production $[8,114]$. ${ }^{\mathrm{i}}$ The costs of wastewater treatment are estimated at $0.04 € \mathrm{l}^{-1}$, based on data from Pimentel et al. [34] and have been corrected for differences in the ethanol yield (in $\mathrm{lt}^{-1}$ cane). It seems that these costs do not take into account the use of wastewater for ferti-irrigation and the increase in water use efficiency and consequently reduction in wastewater production observed during the previous years (Table 4). We include half of the costs calculated by Pimentel et al.

${ }^{j}$ In cane sugar factories $15-20 \%$ of the total investments are required for commonly used installations that protect the environment, not further specified [23]. This probably includes wastewater treatment. We assume that the costs of the conversion of cane to ethanol, which accounts for $40 \%$ of the total costs of ethanol, increase by $20 \%$. 
Table A4 - Cost breakdown of conventional, green, and organic sugarcane production similar to the São Fransisco sugar mill in São Paulo for the year 2004-2005

\begin{tabular}{|c|c|c|c|c|c|c|c|}
\hline \multirow[t]{2}{*}{ Note } & \multirow[b]{2}{*}{ Production system } & \multicolumn{3}{|c|}{$\begin{array}{l}\text { Establishment costs } \\
\qquad\left(€_{2004} \mathrm{ha}^{-1} \mathrm{yr}^{-1}\right)^{\mathrm{a}}\end{array}$} & \multicolumn{3}{|c|}{$\begin{array}{l}\text { Annual harvest costs (average of } 6 \\
\left.\text { cuts; } €_{2004} \mathrm{ha}^{-1} \mathrm{yr}^{-1}\right)^{\mathrm{b}}\end{array}$} \\
\hline & & Conventional & Green & Organic & Conventional & Green & Organic \\
\hline c & $\begin{array}{l}\text { Establishment (average costs distributed per } \\
\text { harvest) }\end{array}$ & & & & 177 & 211 & 293 \\
\hline d & Mechanized operations & 214 & 214 & 214 & 346 & 346 & 346 \\
\hline e & Manual operations & 105 & 157 & 210 & 13 & 66 & 120 \\
\hline $\mathrm{f}$ & $\begin{array}{l}\text { Stems (seeding clones), agrochemicals, } \\
\text { minerals }\end{array}$ & 282 & 354 & 425 & 138 & 138 & 138 \\
\hline $\mathrm{g}$ & Managing costs and taxes & 69 & 72 & 75 & 106 & 120 & 133 \\
\hline $\mathrm{h}$ & Green fertilization & & & 186 & & & \\
\hline i & $\begin{array}{l}\text { New legal environmental compliances/ } \\
\text { certification costs }\end{array}$ & & & & & 14 & 19 \\
\hline j & Total direct costs (running costs) & 670 & 797 & 1110 & 780 & 894 & 1048 \\
\hline k & $\begin{array}{l}\text { Capital costs (habitat/ecosystem } \\
\text { rehabilitation) }\end{array}$ & & & & & 6 & 27 \\
\hline 1 & Total costs & 670 & 797 & 1110 & 780 & 901 & 1076 \\
\hline $\mathrm{m}$ & $\begin{array}{l}\text { Cost comparison (index } 100 \text { for } \\
\text { conventional system) }\end{array}$ & 100 & 119 & 166 & 100 & 115 & 113 \\
\hline
\end{tabular}

See the notes for explanations and sources.

a Sugarcane plantation establishment.

${ }^{\mathrm{b}}$ Ratoon cuts.

${ }^{\mathrm{c}}$ Annual equivalent value obtained from the total foundation costs and distributed per 6 harvests; cuts considering a discount rate of $15 \%$ yr ${ }^{-1}$.

d Source: [130].

e Sources: [130-133].

${ }^{\mathrm{f}}$ Planting products according to each system of production. Sources: [130-133].

Source: [130].

${ }^{\mathrm{h}}$ In the case of organic cane, nitrogen is provided by previous plantation of Stilozobium aterrimum through symbiotic fixation of $\mathrm{N}_{2}$. Sources: $[133,134]$.

${ }^{i}$ Certification costs for organic system at rate of $0.5 \%$ of the row income. Source: [135].

j Overall costs excluding capital costs.

k Source: [136]. The costs are for forest establishment and maintenance during 3 years, for $20 \%$ of the area in case of organic cane (following the legal reserve obligation included in the Forest Code) and for $3.9 \%$ in case of green cane (the average area remaining unprotected).

${ }^{1}$ The data are averaged per harvest; in total 6 harvests are included.

${ }^{\mathrm{m}}$ Cost comparison based on a sugarcane yield of 90,90 , and $110 \mathrm{tha}^{-1} \mathrm{yr}^{-1}$ for conventional, green, and organic cane, respectively. Conventional cane is set at 100

were formulated and scored on four aspects to determine whether an area of concern is a minor, medium or major bottleneck, see Table 17. Aspect 1 'Importance of the area of concern' and 3 'Necessity of improvement strategies' were valued twice as important as the other two aspects when calculating the concluding rating.

The results indicate that eight or nine areas of concern can be classified as a minor bottleneck, six as a medium obstacle, and two or three as a major limitation for a sustainable, certified ethanol production. The most problematic areas of concern are biodiversity, competition with food production, and maybe genetically modified organisms. The areas biodiversity and competition with food production have in common that the indirect and induced impacts of the increase of sugarcane production are potentially significant, indicators and criteria need to be developed on these issues and the costs to overcome these problems are possibly high. Genetically modified cane is at this moment not used, but could become a bottleneck considering the potentially large benefits and advantages on one hand and the uncertainties and potential public resistance on the other hand. For most other areas of concern the scope in our study was limited to direct impacts only, i.e. the impacts within the boundaries of the farm and its employees, which is in line with existing certification systems. Widening of the scope could lead to different outcomes.

Most other criteria are a minor or medium bottleneck. Compliance with these criteria may increase the ethanol production costs by less than $10 \%$ for each of the areas of concern for which specific data are included. But the aggregated costs are likely lower as the example of organic and green ethanol production in the São Fransisco mill in SP indicates: the additional costs of ethanol produced from organic and green ethanol are $8 \%$ and $9 \%$, respectively. The costs of the certification procedure are calculated at $0.5 \%$ of the total production costs. We conclude that the sustainable, certified production of cane is more expensive than conventional cane production, but that the additional costs of compliance with sustainability criteria is likely limited for most criteria.

We acknowledge that the analysis in this article is based on a subjective assessment and evaluation of the different areas 
of concern and also on incomplete information. Further development of a practically applicable and generally accepted ethanol certification system requires additional work on:

1. Data collection: There is a lack of region-specific, up-to-date information about many areas of concern, e.g., the greenhouse gas emissions from land use changes due to changes in soil carbon, the indirect and induced impacts of an increase in sugarcane production on employment, biodiversity and food security, and the level of material welfare of employees in the sugarcane and ethanol sector.

2. Methodology development: There is a need for more accurate methodologies, indicators and criteria to estimate the indirect and induced impacts of ethanol production, which are particularly relevant for the impact on employment, biodiversity and food security, but in principle also for other issues. This goes also for the development of improvement strategies.

3. Stakeholder consultation: There is no consensus about the definition of the term sustainability. Consequently, stakeholder discussions are necessary to reach consensus about the criteria and to create support for a certification system; preliminary stakeholder consultations have already been carried out, see Smeets et al. [14] and Ortiz and Rodrigues [11].

There are many existing certification systems and guidelines that can be helpful when composing a practically applicable certification system.

\section{Acknowledgements}

This study was funded by SenterNovem, The Netherlands Agency for Sustainable Development and Innovation. The study forms part of the programme Strategic Support of International Collaboration (STROIS) of the Ministry of Housing, Spatial Planning and the Environment of the Netherlands.

\section{Appendix A}

See Table A1.

\section{Appendix B}

See Table A2.

\section{Appendix C}

See Table A3.

\section{Appendix D}

See Table A4.

\section{R E F E R E N C E S}

[1] UNICA. Production statistics Center-South Brazil. São Paulo, Brazil: São Paulo Sugar Cane Agroindustry Union (UNICA); 2006 Available online via 〈http://www.portalunica.com.br/ portalunica $>$.

[2] F.O. Licht. World Ethanol and Biofuels Report 2006. Kent, England: F.O. Licht; 2006.

[3] IEA. Álcool: Projeção da Produção e Exportação no Período 2005/06 A 2015/16. São Paulo, Brazil: Instituto de Economia Agricola (IEA); 2006.

[4] Rosillo-Calle F, Walter A. Global market for bio-ethanol: historical trends and future prospects. Energy for Sustainable Development 2006;10:20-32.

[5] Da Motta RS. The social viability of ethanol production in Brazil. Energy Economics 1987;9:176-82.

[6] Moreira JR, Goldemberg J. The alcohol program. Energy Policy 1999;27:229-45.

[7] De Carvalho Macedo I. The sugar cane agro-industryits contribution to reducing $\mathrm{CO}_{2}$ emissions in Brazil. Biomass and Bioenergy 1992;3:77-80.

[8] Macedo IC. Sugar cane's energy. Twelve studies on Brazilian sugar cane agribusiness and its sustainability. UNICA, 2005. p. 237.

[9] De Resende AS, Xavier RP, de Oliveira OC, Urquiaga S, Alves BJR, Boddey RM. Long-term effects of pre-harvest burning and nitrogen and vinasse applications on yield of sugar cane and soil carbon and nitrogen stocks on a plantation in pernambuco, N.E. Brazil. Journal Plant and Soil 2006;281:339-51.

[10] Cançado JED, Saldiva PHN, Pereira LAA, Lara LBLS, Artaxo P, Martinelli LA, et al. The impact of sugar cane-burning emissions on the respiratory system of children and the elderly. Environmental Health Perspectives 2006;114.

[11] Ortiz L, Rodrigues D. Case study sugar cane ethanol from Brazil. Brazil: CREM, Núcleo Amigos da Terra (NAT), Vitea Civilis Institute; 2006. p. 49.

[12] Lewandowski I, Faaij A. Steps towards the development of a certification system for sustainable bio-energy trade. Biomass and Bioenergy 2006;30:83-104.

[13] IEA. Cana-de-açúcar para indústria: o quanto vai precisar crescer. São Paulo, Brazil: Instituto de Economia Agricola (IEA); 2006.

[14] Smeets E, Junginger M, Faaij A, Walter A, Dolzan P. The sustainability of Brazilian ethanol. Utrecht, The Netherlands: Utrecht University, Copernicus Institute; 2006. p. 97+appendices.

[15] Smeets E, Faaij A, Lewandowski I. The impact of sustainability criteria on the costs and potentials of bioenergy production. An exploration of the impact of the implementation of sustainability criteria on the costs and potential of bioenergy production, applied for case studies in Brazil and Ukraine. Utrecht, the Netherlands: Utrecht University, Copernicus Institute; 2005. p. 73+ appendices.

[16] Lewandowski I, Faaij A. Steps towards the development of a certification system for sustainable biomass trade-analysis of existing approaches. Utrecht, The Netherlands: Utrecht University; 2004. p. 69.

[17] Macedo IC, Cortez LAB. Sugarcane industrial processing in Brazil. In: Rosillo-Calle F, Bajay SV, Rothma H, editors. Industrial uses of biomass energy. London: Taylor \& Francis; 2000. p. $140-54$.

[18] Braunbeck OA, Cortez LAB. Sugarcane culture and use of residues. In: Rosillo-Calle F, Bajay SV, Rothma $\mathrm{H}$, editors. Industrial uses of biomass energy. London: Taylor \& Francis; 2000. p. 119-39. 
[19] FAO. AQUASTAT country profiles-Brazil, version 2000. Rome, Italy: United Nations Food Agricultural Organisation; 2004.

[20] Moraes JM, Pellegrino GQ Ballester MV, Martinelli LA, Victoria RL, Krusche AV. Trends in hydrological parameters of a Southern Brazilian watershed and its relation to human induced changes. Water Resources Management 1998;12:295-311.

[21] Matoli CS. Irrigação suplementar de cana-de-açúcar: modelo de análise de decisão para o Estado de São Paulo. Escole Superior de Agriculture "Luiz de Quereiroz". São Paulo, Brazil: Universidade de São Paulo; 1998.

[22] WB. Pollution prevention and abatement handbook. Washington, DC: World Bank; 1998. p. 471.

[23] GTZ. Environmental handbook, vol. II-Agriculture, miningenergy, trade-industry. Eschborn, Germany: Deutsche Gesellschaft für Technische Zusammenarbeid (GTZ); 1995. p. 736.

[24] Braga BPF, Strauss C, Paiva F. Source: water charges: paying for the commons in Brazil. International Journal of Water Resources Development 2005;21:119-32.

[25] Krusche AV, Martinelli LA, Victoria RL, Bernardes M, de Camargo PB, Ballester MV, et al. Composition of particulate and dissolved organic matter in a disturbed watershed of southeast Brazil (Piracicaba River basin). Water Research 2002;36:2743-52.

[26] Lara LBLS, Artaxo P, Martinelli LA, Victoria RL, Camargo PB, Krusche A, et al. Chemical composition of rainwater and anthropogenic influences in the Piracicaba River Basin, Southeast Brazil. Atmospheric Environment 2001;35:4937-45.

[27] Armas ED, Monteiro RTR, Amancio AV, Correa RML, Guercio MA. Uso de Agrotóxicos em Cana-de-Açúcar na Bacia do Rio Corumbataí e o Risco de Poluição Hídrica. Quimica Nova 2005;28:975-82.

[28] Sugar Mark. Cleaner production waste reduction opportunities. Available via /www.iea.ac.zw/santren/projects/ cleanerproduction/tirangle_limited.htm $\rangle, 2006$.

[29] Weed Science. International survey of herbicide resistant weeds. Accessible via 〈www.weedscience.org〉, Corvallis, OR, USA, 2006.

[30] De Armas ED, Monteiro RTR. Uso de agrotóxicos em canade-açúcar na bacia do Rio Corumbataí e o risco de poluição hídrica. Quimica Nova 2005;28:975-82.

[31] PAN. Pesticides database. San Fransisco, USA: Pesticide Action Network (PAN) North America; 2005 Accessible via $\langle$ http://www.pesticideinfo.org/Search_Chemicals.jsp 〉.

[32] UNEP. Stockholm convention on persistent organic pollutants. Châtelaine, Geneva, Switzerland: United Nations Environmental Programme/Secretariat for the Stockholm Convention on Persistent Organic Pollutants; 2001.

[33] FAO. International code of conduct on the distribution and use of pesticides. Rome, Italy: Food and Agricultural Organisation; 2002.

[34] Pimentel D, Warneke FA, Teel WS, Schwab KA. Biomass: food versus fuel. In: Pimentel D, Pimentel M, editors. Food, energy and society. Niwot, CO, USA: Colorado University Press; 1996. p. 227-59.

[35] Goldemberg J. Sustainability of sugarcane ethanol in the state of São Paulo, Brazil. São Paulo State Secretary for the Environment; 2006.

[36] Mittermeyer RA, Myers N, Mittermeyer CG. Hotspots Earth's biologically richest and most endangered terrestrial ecoregions. Arlington, VA, USA: Conservation International; 1999.

[37] Conservation International. Biodiversity hot spots. Washington, DC, USA: Conservation International; 2006 Accessible via 〈http://www.biodiversityhotspots.org/xp/ Hotspots/ $>$.
[38] Carvalho EP. Açúcar \& Álcool: a busca da agilidade. Agroanalysis-a revista de agronegócios da FGV 2001;21.

[39] Sparovek G, Berndes G, Egeskog A, Freitas FLM, Gustafsson $\mathrm{S}$, Hansson J. Sugarcane ethanol production in Brazil: an expansion model sensitive to socioeconomic and environmental concerns. Biofuels, Bioproducts and Biorefining 2007;1.

[40] FAO. FAO stat database. Rome, Italy: United Nations Food Agricultural Organisation; 2005 Accessible via 〈http:// apps.fao.org/page/collections $>$.

[41] Martines-Filho J, Burnquist HL, Vian CEF. Bioenergy and the rise of sugarcane-based ethanol in Brazil. Choices 2006;21:91-6.

[42] Macedo IC, Nogueira LAH. Biocombustíveis (biofuels). Cadernos do Núcleo de Assuntos Estratégicos da Presidência da República 2005;2.

[43] Chomitz KM, Thomas TS, Brandao ASP. The economic and environmental impact of trade in forest reserve obligations: a simulation analysis of options for dealing with habitat heterogeneity. Revista de Economia e Sociologia Rural 2005;43:657-82.

[44] Smeets EMW, Faaij APC, Lewandowski IM, Turkenburg WC. A bottom up quickscan and review of global bio-energy potentials to 2050. Progression in Energy and Combustion Science 2006;33:56-106.

[45] Valdes C. Brazil's booming agriculture faces obstacles. AmberWaves 2006;11.

[46] Quintiliano J, Margues A, Bertoni J, Barreto GB. Perdas por erosão no estado de São Paulo. Brigantia 1961;20:1143-82.

[47] De Maria IC, Dechen S. Perdas por erosão do solo em canade-açú. STAB_Açúcar, Alcool e Subprodutos 1998;17:20-1.

[48] Sparovek G, Schnug E. Temporal erosion-induced soil degradation and yield loss. Soil Science Society of America Journal 2001;65:1479-86.

[49] USDA. National Resources Inventory 2001. Soil erosion. Washington, DC: Natural Resources Conservation Service and Ames, IA, USA: Statistical Laboratory, Iowa State University; 2003. p. 4.

[50] TDEC. Erosion \& sediment control handbook. Nashville, TN: Tenessee Department of Environment and Conservation; 2002. p. 11.

[51] EurepGAP. Fruit and vegetables (various technical documents). Germany: Cologne; 2005.

[52] FSC. FSC principles \& criteria of forest stewardship. Bonn, Germany: Forest Steward Council; 2006 Accessible via $\langle$ http://www.fsc.org/en/about/policy_standards/princ_ criteria $\rangle$.

[53] Troeh FR, Hobbs JA, Donahue RL. Soil and water conservation: productivity and environmental protection. Upper Saddle River, NJ, USA: Prentice-Hall; 1999.

[54] Sparovek G, Schnug E. Soil tillage and precision agriculture: a theoretical case study for soil erosion control in Brazilian sugar cane production. Soil and Tillage Research 2001;61:47-54.

[55] Dobereiner J, Baldani VLD, Reis VM. The role of biological nitrogen fixation to bio-energy programmes in the tropics. In: Rocha-Miranda CE, editor. Transition to global sustainability: the contributions of Brazilian science. Rio de Janeiro, Brazil: Academia Brasiliera de Ciências; 2000.

[56] Oda LM, Soares BEC. Genetically modified foods: economic aspects and public acceptance in Brazil. Trends in Biotechnology 2000;18:188-90.

[57] Fontes EMG. Legal and regulatory concerns about transgenic plants in Brazil. Journal of Invertebrate Pathology 2003;83:100-3.

[58] Contini E, Sampaio MJA, Avila AFD. The lack of clear GMO regulation: its impact on researchers and farmers in Brazil. International Journal of Biotechnology 2005;7:29-45. 
[59] Macedo IC, Leal MRLV, Da Silva JEAR. Assessment of greenhouse gas emissions in the production and use of fuel ethanol in Brazil. Brazil: Secretariat of the Environment of the State of São Paulo; 2004. p. 32.

[60] Braunbeck O, Magalhães PSG. Colheita Sustentável com aproveitamento integral da cane. Visão Agrícola, Esalq-Usp., 2004.

[61] Oliveira MED, Vaughan BE, Rykiel EJ. Ethanol as fuel: energy, carbon dioxide balances, and ecological footprint. Bioscience 2005;55:593-602.

[62] Langer T. Simplified Life Cycle Assessment study of the substitution of $5 \%$ of Swiss gasoline by Brazilian bioethanol. São Paulo: Instituto Ekos Brazil; 2006. p. 26.

[63] Moreira JR. Global biomass energy potential. Journal Mitigation and Adaptation Strategies for Global Change 2006;11:313-33.

[64] NEA. Biocombustíveis. Brasil: Núcleo de Assuntos Estratégicos da Presidência da República; 2005. p. 201+appendices.

[65] OECD. An initial view on methodologies for emission baselines: electricity generation case study. Paris, France: Organisation of Economic Cooperation and Development (OECD); 2001. p. 48+appendices.

[66] IPCC. 2006 IPCC guidelines for national greenhouse gas inventories, vol. 4, Agriculture, forestry and other land use. IPCC, IGIS, 2006.

[67] Schaeffer R, Logan J, Szklo AS, Chandler W, De Souza Marques JC. Brazil's electric power choices and their corresponding carbon emissions implications. Mitigation and Adaptation Strategies for Global Change 2001;6:47-69.

[68] IEA. World energy outlook 2006. Paris, France: International Energy Agency; 2006.

[69] UNFCCC. Approved baseline methodology AM0015 "Bagasse-based cogeneration connected to an electricity grid". UN Framework Convention on Climate Change (UNFCCC); 2004. p. 21.

[70] Moreira JR. Global biomass energy potential. São Paulo, Brazil: Brazilian Reference Center on Biomass; 2004. p. 27.

[71] Carvalho LCCC. Sugarcane as a perfect biomass for energy production. Presentation LAMNET workshop 3 December 2002. UNICA, 2002.

[72] Bayer C, Martin-Neto L, Mielniczuk J, Pavinato A, Dieckow J. Carbon sequestration in two Brazilian Cerrado soils under no-till. Soil and Tillage Research 2006;86:237-45.

[73] Zinna YL, Lala R, Resckb DVS. Changes in soil organic carbon stocks under agriculture in Brazil. Soil and Tillage Research 2005;84:28-40.

[74] Silva JE, Lemainski J, Resck DVS. Perdas de matéria orgânica e suas relações com a capacidade de troca catiônoica em solos da região de cerrados do oeste baiano Reunião Brasileira de Conservação do solo e da Água 1994;18:541-7.

[75] Silveira AM, Victoria RL, Ballester MV, De Camargo PB, Martinelli LA, De Cássia Piccolo M. Simulation of the effects of land use changes in soil carbon dynamics in the Piracicaba river basin, São Paulo State, Brazil. Pesquisa Agropecuária Brasileira 2000;35.

[76] Freitas PL, Blancaneaux P, Gavinelli E, Larré-Larrouy MC, Feller C. Nível e natureza do estoque orgânico de latossolos sob diferentes sistematas do uso e manejo. Pesquisa Agropecuária Brasileira 2000;35:157-70.

[77] FAO. The state of food insecurity in the world 2006. Rome, Italy: Food and Agricultural Organisation of the United Nations; 2006.

[78] FAO. World agriculture: towards 2015/2030. An FAO perspective: United Nations Food Agricultural Organisation. London, UK: Earthscan Publications Ltd.; 2003.

[79] Coulho ST, Goldemberg J, Lucon O, Guardabassi P. Brazilian sugar cane: lessons learned. São Paulo, Brazil: São Paulo State Environmental Secretariat; 2005. p. 23.
[80] IEA. Previsões e Estimativas das Safras Agrícolas de São Paulo. São Paulo, Brazil: Instituto de Economia Agricola (IEA); 2006.

[81] CONAB. Cana-de-Açúcar Primeiro Levantamento Safra 2006-2007. Companhia Nacional de Abastecimento (CONAB); 2006.

[82] OECD. Agricultural market impacts of future growth in the production of biofuels. Paris, France: Organisation of Economic Cooperation and Development (OECD); 2006. p. 55.

[83] Mitchell D. Sugar policies: an opportunity for change. In: Aksoy A, Beghin J, editors. Global agricultural trade and developing countries. Washington DC, USA: World Bank; 2005.

[84] ESMAP. Potential for biofuels for transport in developing countries. Washington, DC, USA: Energy Sector Management Assistance Program (ESMP), Energy and Water Department, World Bank; 2005. p. 182.

[85] Moreira JR, Nogueira LAH, Parente V. Biofuels for transport, development, and climate change: lessons from Brazil. In: Bradley R, Baumers KA, editors. Growing in the greenhouse protecting the climate by putting development first. Washington, DC, USA: World Resources Institute; 2005. p. 25-47.

[86] Simmons CS. Territorializing land conflict: space, place, and contentious politics in the Brazilian Amazon. Journal GeoJournal 2005;64:307-17.

[87] Ustulin EJ, Severo JR. Cana-de-Açúcar: Proteger o ambiente e continuar gerando empregos. Confederação da Agricultura e Pecuária do Brasil (CNA); 2001 Accessible via 〈http:// www.cna.org.br/Gleba99N/Set01/cana01.htm $\rangle$.

[88] Ripoli TCC, Ripoli MLC. Biomassa da cana-de-açúcar: colheita, energia e ambiente, 2004.

[89] Smith G. Towards efficiency in Brazilian agriculture. The OECD Observer 1997;207:28-31.

[90] Scaramucci JA, Cunha MP. Bioethanol as basis for regional development in Brazil: an input-output model with mixed technologies. In: European Regional Science Association Conference 2006, 2006.

[91] UNDP. Human Development Report 2006. New York, NY, USA: United Nations Development Programme; 2006.

[92] DIEESE. Salário mínimo nominal e necessário. Interunion Department of Socioeconomic Studies and Statistics; 2006 Accessible via 〈http://www.dieese.org.br $\rangle$.

[93] OANDA. Currency converter. OANDA Corporation; 2006 Accessible via 〈www.oanda.com〉.

[94] Mutzig JM. The Bolsa Família Grants Program. Presentation held at the international conference on Conditional cash transfers, Istanbul, Turkey, June 26-30. Ministry of Social Development and Hunger Eradication, 2006.

[95] Mendonça ML. The WTO and the destructive effects of the sugarcane industry in Brazil. Land Research Action Network; 2006 Accessible via 〈http://www.landaction.org/ category.php? section $=111\rangle$.

[96] Csillag C, Zorzetto R. Turning point: environmental health in Brazil. Environmental Health Perspectives 2000;108.

[97] Carmargo MLB, Ferreira CRRPT, Fronzaglia T, Ângelo JA, Freitas BB, Ferreira TT. Expenditure on pesticides for the sugarcane in Brazil and in the State of São Paulo. São Paulo: Instituto de Economia Agrícola; 2004.

[98] Schwartzman S, Schwartzman F. O trabalho infantil no Brasil. Jornal do Brasil 2004.

[99] ILO. Database of international labour conventions. International Labour Organisation; 2006 Accessible via 〈http:// www.ilo.org/ilolex/english/convdisp1.htm >.

[100] USDS. Country reports on human rights practices-Brazil. Washington, DC, USA: United States Department of State; 2006. 
[101] Barbosa ML. Internal report. São Paulo, Brazil: Unica; 2005.

[102] Drummond J, Barros-Platiau AF. Brazilian environmental laws and policies, 1934-2002: a critical overview. Law and Policy 2006;28:83-108.

[103] Canegrowers. Code of practice for sustainable cane growing Australia: Brisbane, Australian Cane Growers Council; 2006. p. 23. Accessible via 〈http://www.canegrowers.com.au/dos/ codeofpractice.pdf $\rangle$.

[104] Chen JCP, Chung CC. Cane sugar handbook: a manual for cane sugar manufacturers and their chemists, 12th ed., 1993.

[105] Borrero MAV, Pereira JTV, Miranda EE. An environmental management method for sugar cane alcohol production in Brazil. Biomass and Bioenergy 2003;25:287-99.

[106] SAN/Imaflora. Princípios e Critérios Gerais para Certificação Socioambiental Imaflora/SAN da Cultura da Cana-de-Aç úcar. Institute of Forestry and Agricultural Management and Certification/Sustainable Agricultural Network; 2002.

[107] Fernando LGP. Personal communication with L.G.F. Fernando from Imaflora, 2006

[108] FLO. Fairtrade generic and product standards. Bonn, Germany: Fairtrade Labelling Organizations International; 2006 Accessible via 〈http://www.fairtrade.net/standards.html $\rangle$.

[109] WWF. Better sugarcane initiative. Gland, Switzerland: World Wildlife Fund International; 2006 Accessible via 〈http:// www.panda.org/about_wwf/what_we_do/policy/ agriculture_environment/index/our_solutions/better_sugarcane_initiative/index.cfm $>$.

[110] ESIA. Ethanol and Sugar Impact Analysis (ESIA). Accessible online via 〈http://www.esiaconsulting.com/-About-ESIALabel-.html $>2007$.

[111] GRI. Performance indicators and indicator protocol. Amsterdam, The Netherlands: Global Reporting Initiative; 2006 Accessible via 〈http://www.globalreporting.org $\rangle$.

[112] SAI. Social Accountability 8000 Standard. New York, USA: Social Accountability International; 2006 Accessible via.

[113] Van Dam J, Faaij A. Special article on certification of biomass. Biomass and Bioenergy, 2008, to be published.

[114] Van der Wal-Bake D, Junginger M, Faaij A. Cost reductions of Brazilian ethanol from sugarcane. Biomass and Bioenergy, submitted for publication.

[115] Goldemberg J. The ethanol program in Brazil. Environmental Research Letters 2006;1:1-5.

[116] Silva RMH. Cadeia Produtiva da cana-de-açucar no Brazil e determinantes para seu avanço. Universidade Estadual Paulista, Grupo de Estudos em Economia Industrial; 2004. p. 17.

[117] Dankers C. Environmental and social standards, certification and labelling for cash crops. Rome, Italy: Food and Agricultural Organisation; 2003. p. 120.

[118] Nastari PM. Ethanol: the global overview. In: 2005 international ethanol conference, Ethanol the smart way forward, Brisbane, Australia, 2005.

[119] JC Consultancy. $\mathrm{CO}_{2}$ prices.eu-analysis of the $\mathrm{EU} \mathrm{CO}_{2}$ market, 2007. Accessible via 〈http://www.co2prices.eu/ 〉.

[120] Braunbeck O, Bauen A, Rosillo-Calle F, Cortez L. Prospects for green cane harvesting and cane residue use in Brazil. Biomass and Bioenergy 1999;17:495-506.

[121] IEA. Energy balances of OECD and non-OECD countries. Beyond 20/20 browser, Paris, France, 2002.

[122] IFA. Technology transfer to reduce climate change impacts from the fertilizer industry. Paris, France: International Fertilizer Association; 2004.

[123] WRI. Climate Analysis Indicators Tool (CAIT). Washington, DC, USA: World Resources Institute; 2006 Accessible via $\langle$ http://cait.wri.org/〉.

[124] Giampietro M, Ulgiati S. Feasibility of large-scale biofuel production. Bioscience 1997;47:587-601.
[125] UNICA. Ethanol price statistics. São Paulo, Brazil: São Paulo Sugar Cane Agroindustry Union (UNICA); 2006 Available online via 〈http://www.portalunica.com.br/portalunica $\rangle$.

[126] Pimentel D, Harvey C, Resosudarmo P, Sinclair K, Kurz D, McNair M, et al. Environmental and economic costs of soil erosion and conservation benefits. Science 1995;267:1117-23.

[127] Macedo IC. Converting biomass to liquid fuels: making ethanol from sugar cane in Brazil. In: Goldemberg J, Johansson TB, editors. Energy as an instrument for socioeconomic development. New York, USA: United Nations Development Program; 1995.

[128] Child Right. Agriculture in Brazil. Child Right Worldwide, 2004, Accessible via 〈www.childright.nl/english/ l-bra15.htm >.

[129] ILO. Costs and benefits of education to replace child labour. Geneva, Switzerland: International Labour Organisation; 2002.

[130] FNP. Brazilian Agricultural Yearbook 2005. São Paulo, Brazil: Fundação Nacional de Pesquisa; 2005 [in Portuguese].

[131] Embrapa. Empresa Brasileira de Pesquisa Agropecuária. Sistemas de Produção-Cana Forrageira. Brazilian Agricultural Research Corporation (Embrapa); 2005 Available at 〈www.sistemasdeproducao.cnptia.embrapa.br 〉.

[132] Planeta Orgânico. Interview with L. Balbo Jr., from Usina São Francisco. Report available at <www.planetaorganico.com. $\mathrm{br} /$ native1.htm $>, 2000$.

[133] Souza JL. Agricultura Orgânica-tecnologias para a produç ão de alimentos saudáveis. Vitória, Brazil: Instituto Capixaba de Pesquisa, Assistência Técnica e Extensão Rural (INCAPER); 2005.

[134] Darolt MR, Skora Neto F. Sistema de Plantio Direto em Agricultura Orgânica. Revista Plantio Direto, Passo Fundo 2002;28-31.

[135] Souza MCM. Certificação de Produtos Orgânicos. Políticas Públicas. São Paulo, Brazil: Instituto de Economia Agrícola; 2001 Available at 〈www.iea.sp.gov.br〉.

[136] AES-Tiete. Project design document form for afforestation and reforestation activities. Project Design Document submitted to UNFCCC, São Paulo, Brazil; 2006, Available at 〈www.aestiete.com.br〉.

[137] IBGE. Produção Agrícola Municipal: Culturas Temporárias e Permanentes. Accessible via〈www.ibge.gov.br〉, 2005.

[138] FAPRI. US and world agricultural outlook 2006. Ames, IA, USA: Food and Agricultural Policy Research Institute (IFPRI), Iowa State University, University of Missouri-Columbia; 2006.

[139] Kaltner FJ, Azevedo GFP, Campos IA, Mundim AOF. Liquid biofuels for transportation in Brazil. Potential and implications for sustainable agriculture and energy in the 21st century. São Conrado, São Paulo, Brazil: Fundação Brasileira para o Desenvolvimento Sustentável, commissioned by the German Technical Cooperation (GTZ); 2005. p. 104.

[140] Johnson FX. Bioenergy from sugar cane for sustainable development and climate mitigation: options, impacts and strategies for international co-operation. Stockholm, Sweden: Stockholm Environmental Institute; 2002.

[141] Machado RB, Neto MBR, Pereira PGP, Caldas EF, Gonçalves DA, Santos NS, et al. Estimativas de perda da área do Cerrado brasileiro. Brasil: Conservação Internacional, Oreádes Núcleo de Geoprocessamento, Conservation International; 2004. p. 11+appendices.

[142] Oliveira HR. The Brazilian experience. Seminar: "Assessing the Biofuels Option". Paris, France: International Energy Agency and the United Nations Foundation; 20-21 June, 2005.

[143] Carvalho LCC. Tranformação do Álcool em Commodity. Simposio Internacional e Mostra de Tecnologia da Indústria 
Sucroalcoleira (SIMTEC 2006), 2006, Available at <http:// canaplan.com.br $>$.

[144] Von Blottnitz H, Curran MA. A review of assessments conducted on bio-ethanol as a transportation fuel from a net energy, greenhouse gas, and environmental life cycle perspective. Journal of Cleaner Production 2007;15:607-19.
[145] Leal MRLV. Better sugar, better business. Mill issues and coproducts. Presentation held during the WWW Workshop, London, June 2005.

[146] UNEP. Source book of alternative technologies for freshwater augmentation in Latin America and the Caribbean. Washington, DC: Organization of American States; 1997. 